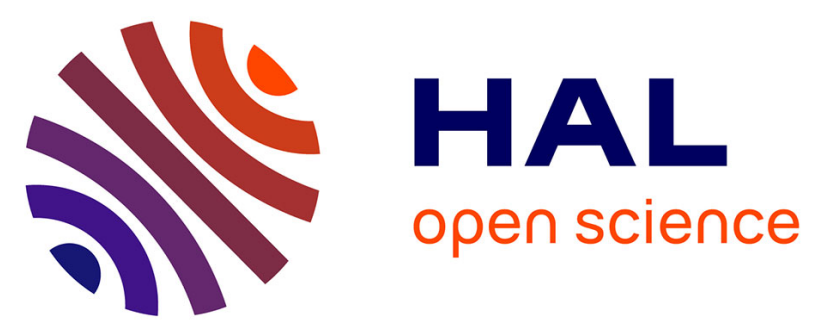

\title{
Ultrastructure of Selenidium pendula, the Type Species of Archigregarines, and Phylogenetic Relations to Other Marine Apicomplexa
}

Joseph Schrével, Andrea Valigurová, Gérard Prensier, Aurélie Chambouvet, Isabelle Florent, Laure Guillou

\section{To cite this version:}

Joseph Schrével, Andrea Valigurová, Gérard Prensier, Aurélie Chambouvet, Isabelle Florent, et al.. Ultrastructure of Selenidium pendula, the Type Species of Archigregarines, and Phylogenetic Relations to Other Marine Apicomplexa. Protist, 2016, 167 (4), pp.339-368. 10.1016/j.protis.2016.06.001 . hal01338422

\section{HAL Id: hal-01338422 \\ https://hal.sorbonne-universite.fr/hal-01338422}

Submitted on 28 Jun 2016

HAL is a multi-disciplinary open access archive for the deposit and dissemination of scientific research documents, whether they are published or not. The documents may come from teaching and research institutions in France or abroad, or from public or private research centers.
L'archive ouverte pluridisciplinaire HAL, est destinée au dépôt et à la diffusion de documents scientifiques de niveau recherche, publiés ou non, émanant des établissements d'enseignement et de recherche français ou étrangers, des laboratoires publics ou privés. 


\section{ORIGINAL PAPER}

3 Ultrastructure of Selenidium pendula, the Type Species of

4 Archigregarines, and Phylogenetic Relations to Other Marine

5 Apicomplexa

6

Joseph Schrével ${ }^{\mathrm{a}, 1}$, Andrea Valigurováb, Gérard Prensier ${ }^{\mathrm{c}, 2}$, Aurélie Chambouvet $^{\mathrm{d}}$, Isabelle Florent ${ }^{\mathrm{a}}$, and Laure Guillou ${ }^{\mathrm{e}}$

${ }^{a}$ Unité Molécules de Communication et Adaptation des Microorganismes, (MCAM, UMR 7245), Muséum National Histoire Naturelle, Sorbonne Universités, CNRS, CP 52, 57 Rue Cuvier, 75005 Paris, France

${ }^{\mathrm{b}}$ Department of Botany and Zoology, Faculty of Science, Masaryk University, Kotlářská 2, 61137 Brno, Czech Republic

${ }^{\mathrm{c} C e l l ~ B i o l o g y}$ and Electron Microscopy Laboratory, François Rabelais University, 10 Boulevard Tonnellé, BP 3223, 37032 Tours Cedex, France

${ }^{\mathrm{d}}$ Laboratoire des Sciences de l'Environnement Marin (LEMAR), UMR6539 UBO/CNRS/IRD/IFREMER, Institut Universitaire Européen de la Mer (IUEM), Technopole Brest Iroise, 29280 Plouzané, France ${ }^{\text {e}}$ Sorbonne Universités, Université Pierre et Marie Curie - Paris 6, CNRS, UMR 7144, Station Biologique de Roscoff, Place Georges Teissier, CS90074, 29688 Roscoff cedex, France

Submitted February 3, 2016; Accepted June 12, 2016

Monitoring Editor : Frank Seeber

Running title: Selenidium pendula: Ultrastructure and Phylogeny

${ }^{1}$ Corresponding author; fax +331407934 99

e-mail schrevel@mnhn.fr (J. Schrével).

${ }^{2}$ This work is dedicated to the memory of Brigitte Arbeille-Brassart 
Archigregarines, an early branching lineage within Apicomplexa, are a poorly-known group of invertebrate parasites. By their phylogenetic position, archigregarines are an important lineage to understand the functional transition that occurred between freeliving flagellated predators to obligatory parasites in Apicomplexa. In this study, we provide new ultrastructural data and phylogenies based on SSU rDNA sequences using the type species of archigregarines, the Selenidiidae Selenidium pendula Giard, 1884. We describe for the first time the syzygy and early gamogony at the ultrastructural level, revealing a characteristic nuclear multiplication with centrocones, cryptomitosis, filamentous network of chromatin, a cyst wall secretion and a 9+0 flagellar axoneme of the male gamete. $S$. pendula belongs to a monophyletic lineage that includes several other related species, all infecting Sedentaria Polychaeta (Spionidae, Sabellaridae, Sabellidae and Cirratulidae). All of these Selenidium species exhibit similar biological characters: a cell cortex with the plasma membrane - inner membrane complex - subpellicular microtubule sets, an apical complex with the conoid, numerous rhoptries and micronemes, a myzocytosis with large food vacuoles, a nuclear multiplication during syzygy and young gamonts. Two other distantly related Selenidium-like lineages infect Terebellidae and Sipunculida, underlying the ability of archigregarines to parasite a wide range of marine hosts.

2

3

Key words: Archigregarines; Apicomplexa; Selenidium pendula; ultrastructure; phylogeny; sporozoite.

\section{Introduction}

Apicomplexa, a large subgroup of the Alveolata, are unicellular parasites infecting a wide range of invertebrate and vertebrate hosts. Most known Apicomplexa belong to Coccidia and Haemosporidia and are involved in human and veterinary diseases (malaria, toxoplasmosis, coccidiosis, babesiosis, piroplasmosis). However, a very large group of the early branching Apicomplexa, the gregarines, is comparatively poorly known. Most of the gregarines infect invertebrate hosts and usually do not have deleterious effects on their 
hosts (Desportes and Schrével 2013). The number of Apicomplexa species is estimated to be $\sim 2,000-6,000$, however the ability of gregarines to infect a wide range of insects could significally enhance this estimation to several thousand or more than one million (e.g., the Coleoptera (beetles) class corresponds to about $40 \%$ of the insect biodiversity with an expected species number around 1 to 2 million) (Schrével and Desportes 2013).

All apicomplexan species are characterized by an infective life stage, the so-called zoite, a polarized cell with an original apical complex. This apical complex is an assembly of specific organelles including club-shaped rhoptries, filament-like micronemes, dense granules and apical polar rings. In Apicomplexa, the presence of a conoid in the apex of the zoite, observed in coccidia and gregarines, defines the Conoidasida Levine, 1988. In contrast, no conoid is observed in Haemosporidia and Piroplasmida designated Aconoidasida by Mehlhorn et al. (1980). Except gregarines and some other taxa developing in epicellular localization, such as cryptosporidia, most Apicomplexa have an intracellular development in their host cells and there, the apical organelles as well as the conoid, play an essential role in cell invasion processes through sophisticated cascades of molecular interactions (Boothroyd and Dubremetz 2008; Bradley et al. 2005; Santos et al. 2009). In Apicomplexa displaying an intracellular life style, the cycle usually occurs in two hosts, the sexual phase being performed in the definitive host while asexual phases occur in one or several intermediate hosts. Gametogenesis, as observed in Coccidia or Haemosporidia, exhibits a clear anisogamy with production of small flagellated male gametes (microgametes) and large non-flagellated female gametes (macrogametes). After fertilization, the sporogony produces sporozoites in the definitive hosts while asexual schizogny or merogony, producing merozoites, is realized in intermediate hosts. In contrast, most gregarines exhibit an extracellular development and their entire life cycle usually occurs within a single host. Their zoites transform into large vegetative cells, the trophozoites, with an extraordinary diversity in their morphologies and behaviours. In addition to this extracellular development, gregarines share a unique sexual phase. The sexual association between two gamonts, named syzygy, produces a cyst where the gametogenesis differentiates a large and equal number of male and female gametes; at this stage, this cyst is called a gametocyst. Then, fertilization and sporogenesis take place within the cyst yielding the final stages with the sporocysts usually containing each 8 sporozoites. These sporocysts can survive for a long period generally waiting for their ingestion by their specific hosts. Gregarine biochemistry and physiology are still poorly documented. Studies of their zoite apical apparatus as well as of the variation of their 
102 cytoskeleton and microtubule organizing centers (MTOCs), with unique organization as the

$1036+0$ or $3+0$ flagellar axonemes described for some male gametes (Prensier et al. 1980;

104 Schrével and Besse 1975), contributed, however, to a more general understanding of many

105 biological aspects of Apicomplexa including pathogenic species.

106 Among Apicomplexa, there is a consensus on the stem group of archigregarines 107 commonly found in Polychaeta, Sipunculida and some Hemichordata. These marine 108 gregarines represent the earliest diverging lineage of Apicomplexa (Leander 2007a; 109 Schrével 1971b). The type species of archigregarines is Selenidium pendula Giard 1884 and 110 its life cycle was established during the second part of the $20^{\text {th }}$ century (Schrével 1966, 111 1970). Beside this type species, a long series of contributions have been performed on other 112 Selenidium and related species at the cytological (Brasil 1907, Caullery and Mesnil 1899, 113 2000, Ray 1930, Reed 1933) and ultrastructural (Leander 2006, 2007b; Macgregor and 114 Thomasson 1965; Schrével 1968, 1970, 1971a; Simdyanov and Kuvardina 2007, Vivier 115 and Schrével 1964, 1966) levels and more recently also at the molecular level through the 116 analysis of SSU rDNA sequences (Leander et al. 2003; Leander 2006, 2007b; Rueckert and 117 Leander 2009; Wakeman and Leander 2012, 2013; Wakeman et al. 2014). Most of these 118 studies focused on the trophozoite stages with few descriptions on nutrition modalities 119 (Schrével 1968; Simdyanov and Kuvardina 2007). Additionally, these studies highlighted 120 several incongruities among Selenidiidae at the molecular level that could not be elucidated 121 in absence of the type species of the family. Here, we report on the cell organization of the 122 Selenidium pendula trophozoite with a special attention to the conoid, the abundance of 123 rhoptries and micronemes, and we provide the first ultrastructural description of the syzygy 124 (pairing stage), the early gamogony with the cryptomitosis and the secretion of the cyst 125 walls. We also provide the first phylogenetic analysis of the SSU rDNA gene sequences 126 encompassing the type species of archigregarines S. pendula. Molecular phylogenetic 127 analyses revealed three lineages within archigregarines, $S$. pendula belonging to the 128 Selenidiidae that includes parasites of Spionidae, Sabellidae, and Sabellariidae, all 129 polychaete annelids, as well as two Selenidiidae-like lineages, parasites of hosts belonging 130 to Terebellidae and Sipunculida, respectively.

\section{Results}


135 The mature $S$. pendula trophozoite is a crescent-shaped cell of about $150 \mu \mathrm{m}$ in length with 136 a circular cross section of about $35 \mu \mathrm{m}$ in diameter. The cell surface exhibits about 30 137 striations in phase contrast light microscopy as well as in scanning electron microscopy 138 (SEM), appearing as a series of longitudinal bulges of about 2.5-3 $\mu \mathrm{m}$ in width separated 139 by grooves (Fig. 1A). The trophozoite is inserted into the intestinal epithelium of the 140 Scolelepis squamata polychaete worm by a special apical apparatus called the mucron (Figs 141 1B, 2A-C). In transmission electron microscopy (TEM), a tropism for host cells rich in 142 granules can be observed (Fig. 1B). The mucron of $S$. pendula corresponds to the 143 attachment apparatus anchoring the parasite to the host epithelial cell. In SEM, the mucron appears as a regular mammiliform area without bulges and grooves (Fig. 2A). After detachment of the trophozoite, the trace of the mucron in the host cell is very regular with

146 $158)$. sometimes a small hole in a subcentral position (Fig. 2B).

A series of short microvilli is seen at the periphery of the epithelial cells (Fig. 2B). All around the trophozoite attachment, numerous long ciliary structures of the host epithelium are observed (Figs 1A, 2B).

Asexual schizogony in $S$. pendula could be an explanation to the exceptional clotting of trophozoites, with thousands and thousands of cells that obstruct the intestinal lumen of some Scolelepis squamata hosts. In vivo, trophozoites are dispersed along the host intestine, except for the first thirty segments. The distinction between these two intestinal regions is facilitated by the yellow color of the first segments versus the green color of the posterior region. Motility of the $S$. pendula trophozoites is clearly of pendular type, as proposed by Giard (1884) for the species diagnosis, and the stroboscopic records show regular pendular beats with a period of about 0.2 second (Golstein and Schrével 1982

In TEM cross sections, the bulges of $S$. pendula exhibit a characteristic ultrastructure described for the first time in Selenidium hollandei (Vivier and Schrével 1964). The plasma membrane is underlain by a regular flat vesicle designated as the inner membrane complex (imc) while a very slight cell coat covers the cell surface. Under these three cortical membranes, a regular set of longitudinal subpellicular microtubules and some other dispersed microtubules within the cortical cytoplasm are seen below the bulges but not in the area of the grooves (Fig. 3B-C). In TEM cross sections, each subpellicular microtubule of S. pendula is surrounded by an electron-lucent sheath (Fig. 3C) as observed in S. hollandei (Vivier and Schrével 1964), Platyproteum (Selenidium) vivax (Leander 
2006), Selenidium serpulae (Leander 2007) and Selenidium terebellae (Wakeman et al. 2013). Abundant mitochondria are present under the subpellicular network of the bulges.

Different ectoplasmic structures along the grooves are observed with lamellar elements, dense material structures that crossed the imc and are in contact with the plasma membrane (Fig. 3B, D-F). Under SEM, series of holes are observed in the grooves with an irregular distribution and distances ranging from $0.3-0.4 \mu \mathrm{m}$ to $0.8-0.9 \mu \mathrm{m}$ (Fig. 3A). Such a distribution seems to correspond to the opening sites of the above-mentioned ectoplasmic structures and their density might indicate a role that was previously underestimated.

Interestingly, the longitudinal microtubular bundles, abundantly distributed beneath the cortex in the trophozoite apical part corresponding to the mucron, could represent the biogenesis site of the longitudinal networks of the subpellicular microtubules (Fig. 2D).

\section{Conoid and Myzocytosis}

The conoid of $S$. pendula is a truncated cone of about $225 \mathrm{~nm}$ height, with apical and distal diameters about $260 \mathrm{~nm}$ and $1 \mu \mathrm{m}$ respectively (Fig. 4A-C). In TEM cross sections, the diameter of filaments is about $23-32 \mathrm{~nm}$; 9 sections are well identified in one side of the conoid, while only an opaque layer can be observed on the other side due to their spiral organization (Fig. 4B-C). This structure is quite similar to the well-described conoid of Toxoplasma gondii (Hu et al. 2002, 2006) but the apical polar ring is not present in the distal part of $S$. pendula mucron and the preconoidal rings are not clearly identified in its apical part but a dilatation of the imc and the ends of the subpellicular microtubules are unambiguously demonstrated (Fig. 4A, C, white arrows). This imc dilatation could correspond to a site of a Microtubule Organizing Center (MTOC) able to generate the subpellicular microtubules since abundant bundles are found in the anterior area of the trophozoite (Fig. 2D). In few TEM cross sections, dense structures corresponding to the neck of the rhoptries are observed inside the conoid (Fig. 2C).

Myzocytosis, the predatory mode of nutrition characteristic of archigregarines, is clearly illustrated in S. pendula with food vacuoles inserted inside the conoid (Figs. 2C, 4A-B). In the axis of the mucron, one or several clear food vacuoles, likely formed via the conoid, are present (Fig. 2C). These food vacuoles are surrounded by many rhoptries and micronemes, two apical organelles characteristic of zoites (Figs 1B, 2C). As shown by the continuity of the food vacuole membrane up to its contact with the host epithelial cell, an evagination process through the apex of the conoid has occurred, allowing the parasite to suck out the nutriments from the host. This myzocytosis process starts at the top of the 
conoid (Fig. 4A). The food vacuoles are large, reaching sometimes up to $7 \mu \mathrm{m}$, and several

203 additional food vacuoles of about 2 or $3 \mu \mathrm{m}$ are observed in the axis of the trophozoite

204 (Figs 2C, 5A-B). The lumen of the food vacuoles has a low electron-dense aspect with

205 some vesicles and the membrane of the food vacuole exhibits a very irregular border with

206 numerous digitations.

207 Vital staining with low concentrations of neutral red $(1 \%$ allowed to visualize

208 large vacuoles of about $4 \times 2 \mu$ m located in the apex of the $S$. pendula trophozoite with

209 several small vesicles (data not shown). This observation is in agreement with a

210 fragmentation of the initial food vacuole into numerous vacuoles present in the anterior part

211 of the trophozoite (Fig. 5A).

212

213 Rhoptries, Micronemes, and Intrareticular Granules in Trophozoites

214 In addition to the conoid, the apical end of $S$. pendula trophozoites exhibits about 8-10

215 rhoptries corresponding to the long, electron-dense club-shaped, tubular or saccular

216 organelles. They appear in the trophozoite as cylindrical organelles reaching up to $6 \mu \mathrm{m}$ in

217 length, with a diameter of 0.3-0.4 $\mu \mathrm{m}$ in the basal bulbous. At the apex, a rhoptry neck

218 could be observed. The rhoptry orientation usually follows the direction of the conoid. In

219 some cases, the rhoptry neck penetrates the conoid (Fig. 2C).

220 The rough endoplasmic reticulum (RER) and the Golgi apparatus of S. pendula

221 show an original association between the swollen cisternae containing numerous

222 intrareticular granules of about $0.5-1 \mu \mathrm{m}$ and the first saccule of the cis-region of the Golgi

223 apparatus (Fig. 6D). Similar associations are observed in S. hollandei (Vivier and Schrével

224 1966) but not in Selenidiidae species parasitizing Cirratulidae (Schrével 1971), Serpulidae

225 (Leander 2006), Terebellidae (Wakeman et al. 2014) or Sipunculida (Simdyanov and

226 Kuvardina 2007, Leander 2007). Some micrographs show an accumulation of numerous

227 micronemes close to the nuclear envelope (Fig. 7D) or to the Golgi apparatus (Fig. 6C)

228 with annular sections likely corresponding to the neck of micronemes (Fig. 6B). The

229 relation of these RER-Golgi apparatus to the biogenesis of the rhoptries and/or the

230 micronemes is not clear, since numerous micronemes are mixed with large rhoptries (Fig.

$2316 \mathrm{~A})$.

232

233 Nucleus and the Perinuclear Cytoplasm 
234 The ovoid nucleus of the $S$. pendula trophozoite is characterized by the presence of a large

235 spherical nucleolus of about 4-5 $\mu \mathrm{m}$ in diameter (Fig. 7A). No accumulation of chromatin

236 is observed in the nucleoplasm and the nuclear envelope lacks the nuclear lamina as

237 observed in S. hollandei (Schrével 1971a; Vivier 1967). The nuclear envelope, typically

238 comprising two membranes, is rich in nuclear pores (about 5 per $\mu \mathrm{m}$ ) regularly distributed

239 all over the entire nuclear surface (Fig. 7C). In tangential sections, the pores appear as rings

240 of about $100-110 \mathrm{~nm}$ in their largest diameter with the presence of a central particle of 241 about $10 \mathrm{~nm}$ in diameter (Fig. 7C).

242 The periphery of the nucleus exhibits a special cytoplasmic area comprising a 243 regular, $0.5 \mu \mathrm{m}$ thick fibrillar zone, lacking any organelle, and surrounding the nucleus in a 244 distance of 1.5-2 $\mu \mathrm{m}$ from the nuclear envelope (Fig. 7A-B, E). This fibrillar zone 245 corresponds to the axial ducts described in living cells (Schrével 1970).

\section{Apicoplast-like Organelles}

248 In the trophozoite of $S$. pendula, organelles with four membranes are frequently observed

249 (Fig. 5C) and they appear morphologically similar to the apicoplast of Toxoplasma and

250 Plasmodium (Lim and McFadden 2010) with some dense structures (Fig. 5D) or in contact

251 with multilamellar organelle (Fig. 5E).

\section{Nuclear Multiplication During the Syzygy and Young Gamonts}

254 The sexual phase of the $S$. pendula life cycle starts with the syzygy, characterized by the 255 pairing of two haploid trophozoites, now called gamonts: one male and one female. During 256 the young syzygy stage of $S$. pendula, the two gamonts are linked by their posterior parts, 257 while their pendular motility continues with waves starting from the apex to the posterior 258 end (Schrével, 1970).

259 In TEM, each gamont exhibits a similar intracellular organization with a nucleus of 260 about $20 \mu \mathrm{m}$ in diameter containing a spherical nucleolus of about $5 \mu \mathrm{m}$ in diameter 261 (Supplementary data 1). In each nucleolus, several clear areas are observed with sizes 262 varying from 0.3 to $1 \mu \mathrm{m}$ in diameter (Supplementary data 1, arrows). The cell surface and 263 the cytoplasm of the two gamonts also exhibit a similar organization (Supplementary data $2641)$.

A clear characteristic of archigregarines belonging to the family Selenidiidae is the 266 early nuclear multiplication within the two gamonts at the site corresponding to the initial 267 trophozoite nucleus that occurs before the encystment of the gamonts. The localization of 
268 the nuclei at the initial site of the trophozoite nucleus is clearly shown by the DAPI staining

269 highlighting the DNA-containing structures (Fig. 8A-B). Bright spots are observed inside 270 spherical structures, each of them corresponding to a nucleus. In about two hours, the 271 pendular motility of each gamont is progressively reduced and cyst formation occurs with a 272 widening of the nuclear zone in the gamont's median plane (Fig. 8A-B). In TEM, the 273 concentration of the nuclei at this stage is not easy to observe due to the relatively high rate 274 of this process. In favourable cross sections, the nuclei are observed in the central area of 275 the gamont and before the secretion of the cyst wall. Each spherical nucleus is about $5 \mu \mathrm{m}$ in diameter (Fig. 8C). From this central site, the nuclei migrate to the periphery of each gamont while the cyst wall is forming (Fig. 8D). In many nuclei of the gamonts, centrocones and other stages of cryptomitosis were detected.

281 The mitosis in $S$. pendula gamonts is a closed-mitosis, also called cryptomitosis, with the 282 persistence of the nuclear envelope as observed in all Apicomplexa (Francia and Striepen 283 2014). All the nuclei of the $S$. pendula gamonts are spherical with a diameter of about $5 \mu \mathrm{m}$ 284 and many are associated to a cupule with microtubules radiating from the Microtubule 285 Organizing Center (MTOC) in order to form half-spindles (Fig. 9A-B). The chromatin is 286 localized all around the internal face of the nuclear envelope as shown in TEM images (Fig. 287 9A-B). This chromatin forms an electron dense filamentous network with spotty dark nodes 288 and in some cases, an important dense accumulation is observed inside the nucleoplasm 289 (Fig. 9A). This dense accumulation of at least $1 \mu \mathrm{m}$ could correspond to the bright spots 290 visualized by the DAPI-staining (Fig. 8B). The distribution of chromatin in S. pendula 291 nucleus appears as a continuous filamentous network quite similar to the model of 292 Apicomplexa cryptomitosis proposed by Francia and Striepen (2014).

293 In $S$. pendula gamonts, many nuclei exhibit a centrocone resulting probably from 294 the high rate of nuclear divisions since the chronology from the syzygy to the encystment 295 of the gamonts represents only 2-3 hours (Schrével 1970). The centrocone depends upon 296 the MTOC that appears as an electron dense annular structure of about $200 \mathrm{~nm}$ in diameter. 297 From the MTOC, microtubules radiate and form a half-spindle that pushes the nuclear envelope without penetration in the nucleus (Fig. 9A). The resulting cupule exhibits an

299 outer diameter of about 1.6-1.9 $\mu \mathrm{m}$ and the distance from the MTOC to the inner border of 300 the cupule is about 1.4-1.6 $\mu \mathrm{m}$. This typical centrocone can duplicate and the second 301 centrocone migrates to the opposite direction of the initial cupule (Fig. 9B). Micrographs 
with two centrocones are rather rare and an intranuclear spindle was not observed most likely due to the high rate of the progamic nuclear division in S. pendula.

As the progamic nuclei migrate from the central part of the gamont to the periphery, the cryptomitosis continues after this migration, since the duplication of the centrocones is observed in the border of the cyst where the wall is secreted.

\section{Modifications of the Gamont Cell Surface and Secretion of the Gametocyst Wall}

When the gametocyst wall is forming, the cortical membranes of each gamont are strongly modified (Fig. 10A-C). The plasma membrane is always present but the imc is disorganized with a series of folds and clear dissociation from the plasma membrane (Fig. 10B-C). In TEM, the gametocyst wall exhibits two major layers, a homogeneous internal layer of about 500-700 $\mathrm{nm}$ in thickness and a fuzzy external layer with long filaments reaching about $300 \mathrm{~nm}$. The total thickness of the gametocyst wall at the beginning of gamogony is about $1 \mu \mathrm{m}$. The secretion of this wall is the result of two types of vesicles, one with rather electron dense components (vesicle 1) and the second with a network of very spotty filaments (Fig. 10A). The mechanism of discharge of these two types of vesicles was not clearly observed. As the gametocyst wall formation occurs only two hours after the early syzygy step, the secretion is probably the result of accumulations of numerous intrareticular granules in the cisterns of the rough reticulum endoplasm that represent storage material for this process (Fig. 6D). However, a potential dual function of the RER-Golgi apparatus for both the formation of rhoptries and micronemes and the storage of material for gametocyst formation needs further investigations (Fig. 6A).

\section{The Gametocyst and the Sporocyst Walls}

The gametogenesis is a fast process in S. pendula, lasting about one hour (Schrével 1970). After the series of progamic nuclear divisions yielding syncytium nuclei in the same gametocyst, cellularization occurs, producing flagellated male gametes and female gametes without flagellum. In TEM, the gametocyst wall is more compact with dense layers (Fig. 11A-B). The fuzzy coat observed at the beginning of the gamogony is now very irregular in width and the internal homogenous layers are more electron dense (Fig. 11A). In some cases the internal layers show a regular opaque layer of $0.3 \mu \mathrm{m}$ and an irregular homogenous layer with a lower electron density (Fig. 11A). 
In cross sections, the flagellar axoneme of the male gamete of $S$. pendula exhibits a

$3359+0$ pattern (Fig. 11B2). After fecundation, the life cycle moves into the sporogony phase

336 with the formation of sporocysts corresponding to the evolution of the zygotes toward the

337 sporozoite formation inside each sporocyst. A new secretion process occurs around this

338 sporocyst (Fig. 11C). The thickness of the sporocyst wall is about $0.1 \mu \mathrm{m}$ with small thin

339 spine-like digitations of about $0.2 \mu \mathrm{m}$ (Fig. 11C).

\section{Molecular Phylogenetic Analyses of the SSU rDNA Sequence}

342 Type species are important to build solid bridges between molecular phylogenies and 343 taxonomy. A phylogenetic tree was constructed using 115 sequences including nine novel 344 small subunit (SSU) rDNA sequences (two sequences from $S$. pendula, the type species for 345 Selenidiidae, one from S. hollandei, one from Lecudina pellucida, the type species for 346 Lecudinidae, and 5 from L. tuzetae, all specimen isolated from host organisms collected in 347 the Roscoff area, France) and 106 previously published ones available from public 348 databases, taking into account all available data for archigregarine species (Table 1).

349 Sequences known to produce extreme long branches in SSU rDNA-based phylogenies, 350 such as those of the gregarines Trichotokara spp. and Pyxinia robusta, were excluded from 351 this analysis. Globally, the Maximum Likelihood and the Bayesian tree topologies were 352 congruent (Fig. 12) and in good agreement with recently published phylogenies (Wakeman 353 and Leander 2013; Wakeman et al. 2014). The two early lineages emerging among 354 Apicomplexa were from marine gregarines with archigregarines and eugregarines. 355 Interestingly the phylogenetic position of the type species Lecudina pellucida (Fig. 12) fell 356 within the Lecudinidae, with a good support with lecudinids of tunicates represented by the 357 Lankesteria genus. In the terrestrial gregarines, the Gregarina lineage belongs to rather old 358 insects such as Coleoptera, Blattaria, and Orthoptera, in contrast to the Ascogregarina 359 lineage that infects more recent insects according to the most recent knowledge on insect 360 evolution (Misof et al. 2014).

361 An analysis of the SSU rDNA sequences clearly demonstrated the paraphyly of 362 Selenidiidae, which are split into three major groups (Fig. 13, Supplementary Material 2-4).

363 The type species Selenidium pendula is closely related to Selenidium boccardiella 364 (Wakeman and Leander 2013). These two gregarines infect members of the Spionidae 365 family of Polychaeta. Similarly, S. hollandei is closely related to S. neosabellariae and $S$. 366 identhyrsae (Wakeman and Leander 2013), these three species being parasites of hosts 
belonging to Sabellariidae. Parasites infecting Spionidae and Sabellariidae diverged from 3.4 to $13.7 \%$ from each other (sequence identity, Supplementary Material 2, 3).

Selenidium parasites of Terebellidae group form a second divergent lineage with a wider global divergence with true Selenidiidae of 25.8-28.2 \%, (Supplementary Material 2,

371 3). Finally, all Selenidiidae described in Phascolosoma formed a third group which is the 372 most divergent (26.3 - $28.8 \%$ of divergence with the two precedent groups, Supplementary 373 Material 2, 3).

\section{Discussion}

\section{Selenidium spp. and archigregarines}

378 Since 2003, the morphology of some trophozoites of Selenidiidae and related archigregarines was investigated using SEM and more than 25 SSU rDNA sequences were deposited in the GenBank/EMBL/DDBJ databases (Leander 2003, 2007; Leander et al. 2003; Rueckert and Leander 2009; Wakeman and Leander 2012, 2013; Wakeman et al. 2014). However, data on sexual stages (gamogony and sporogony) were missing. By combining electron microscopic descriptions with phylogenies using SSU rDNA sequence

384 data, new Selenidium species have been proposed such as S. pisinnus Rueckert and 385 Leander, 2009, S. boccardiella Wakeman and Leander, 2012, S. idanthyrsae Wakeman and Leander, 2012, S. neosabellariae Wakeman and Leander, 2013, S. sensimae Wakeman and Leander, 2013 and S. melongena Wakeman et al., 2014. A new genus Platyproteum

388 (Rueckert and Leander 2009) was erected to replace the former species Selenidium vivax 389 (Gunderson and Small 1986). A new enigmatic genus related to archigregarines was also 390 proposed as Veloxidium (Wakeman and Leander 2013). In their discussion, Leander and 391 co-workers produced a comparative table with morphological data of all Selenidiidae 392 described in the last century (Ray 1930; Schrével 1970, 1971). Few mistakes within 393 Selenidiidae were reported in this table (table 2 in Wakeman and Leander 2012) as for 394 example the mention of S. spionis, presented as a parasite of Polyrabdina spionis. 395 Polyrhabdina spionis is in fact a lecudinid gregarine and the host of S. spionis is the 396 polychaete Scolelepis fuliginosa (Claparède, 1870) now called Malacoceros fuliginosus 397 (Claparède, 1870) (Schrével and Desportes, 2013). However, the SSU rDNA sequences 398 analysis of $S$. spionis revealed lineages inside archigregarines and Leander and co-workers 399 underlined the importance of future work on additional Selenidium-like gregarines 
especially the type species $S$. pendula (Wakeman et al 2014). This current work on the type species S. pendula Giard, 1884 and on S. hollandei Vivier and Schrével, 1966 therefore enlighten with less ambiguities parts of the evolutionary history of archigregarines.

The SSU rDNA sequence phylogeny trees with the different SSU rDNA sequences of archigregarines (Table 1), show three clearly delimited lineages among Selenidiidae (Figs 12-13, Supplementary Material 3, 4). A major group corresponds to the trueSelenidium lineage, for which sexual stages (syzygy to sporocyst) have been described. Its members are parasites of Sedentaria polychaetes, such as $S$. pendula that infects the Spionidae family, S. hollandei infecting Sabellariidae and Selenidium cf. meslini infecting Sabellidae. These true-Selenidium share common important features, such as a nuclear multiplication during the syzygy, the gamogony and the sporocysts with usually four sporozoites. Many archigregarines have developed atypical variations in their cell morphology and their motility from pendular to rolling type, with subpellicular microtubule sets under the inner membrane complex (imc), but without the gliding type observed in eugregarines. Trophozoites of true-Selenidium exhibit a three-membrane cortex where the imc forms a complete envelope underlying the plasma membrane, with sets of longitudinal subpellicular microtubules running under the large folds designated as bulges (Schrével 1970a, 1971a; Schrével et al. 2013; Vivier and Schrével 1964). The grooves correspond to the striations well described this last century by light microscopic (Brasil 1907; Ray 1930; Schrével 1970). The cytoplasm beneath the grooves is devoid of microtubules but exhibits micropores and residual membranous organelles in connection with the imc (Schrével et al. 2013; Vivier and Schrével 1964). These parasites feed by myzocytosis using the conoid located at the apex of the trophozoite (Schrével 1968, Simdyanov and Kuvardina 2007, this work).

In this true-Selenidium lineage, the sexual stage starts by the syzygy where the formation of progametic nuclei is observed inside the gamont nucleus before encystment. This observation in the type species S. pendula (Fig. 8) is the confirmation of histological previous descriptions by Caullery and Mesnil (1900), Ray (1930), Reed (1933), Tuzet and Ormières (1958) and in vivo observations by Schrével (1970). This gamogony is quite different from all other eugregarines where the first gamogony division starts inside the cyst and is followed by successive series of nuclear divisions called progamic mitoses without cytokinesis such as in Lecudina tuzetae (Kuriyama et al. 2005). So, the Lecudina type gamogony produces a syncytium until the cellularization process yielding the gametes. Another clear difference concerns the degree of condensation of the chromatin with a 
434 continuous filamentous network attached to the nuclear envelope all around the nucleus in

435 S. pendula cryptomitosis. Chromosome condensation does not seem to occur in S. pendula 436 in contrast to cryptomitosis of L. tuzetae (Kuriyama et al. 2005) and Grebnickiella gracilis 437 (Moblon-Noblot 1980). Sporogony then leads to spherical sporocysts that differentiate 438 usually into four sporozoites per sporocyst (Ray 1930; Schrével 1970).

439 Other Selenidium-like species infecting sipunculids and Terebellidae are only 440 known through their trophozoites and their localization within hosts (Leander 2006; 441 Wakeman et al. 2014). The intestinal trophozoite of S. terebellae Ray 1930 exhibits large 442 bulges but differences with the true-Selenidium have been observed. As an example, a 443 regular layer of about 30-33 $\mathrm{nm}$ in thickness (Supplementary Material 5 and Wakeman et 444 al. 2014) similar to the internal lamina of eugregarines (Schrével et al. 1983) or to some 445 euglenoid cortex (Mignot 1966) is attached to the imc. Numerous sets of longitudinal 446 subpellicular microtubules are immediately under this regular dense layer and many 447 residual membranous organelles are highly concentrated under the imc of the grooves 448 (Supplementary Material 5). S. melongena trophozoites were described in the same host as 449 S. terebellae, but inside the coelom, an unusual localization for archigregarines (Wakeman 450 et al. 2014). The cortex of S. melongena exhibits 30-40 epicytic folds helically arranged 451 along the axis of the cell. Surprisingly, although the subpellicular sets of microtubules were 452 not observed in TEM, a strong fluorescent labelling of alpha-tubulin was detected below 453 the helical folds. S. melongena are non-motile without pendular or rolling motility nor 454 gliding. According to Wakeman et al. (2014), such atypical cell organization of $S$. 455 melongena trophozoites seems to be closer to lecudinids than to Selenidiidae. These 456 original observations as well as the lack of description of syzygy and sporocysts require 457 future work, especially to explain the way by which S. melongena can infect its host.

The third Selenidium-like lineage described here corresponds to a group of intestinal 460 parasites of Sipunculida. These parasites are mainly known from SEM and TEM 461 observations on Selenidium vivax trophozoites (Leander 2006). Renaming of S. vivax as 462 Platyproteum vivax was supported by archigregarine flat shape when observed under TEM 463 with important sets of longitudinal subpellicular microtubules and numerous mitochondria 464 probably in relation to the very active plasticity of S. vivax (Rueckert and Leander 2009). 465 This cellular organization appears similar to that of $S$. hollandei (Schrével 1970). Here also, 466 descriptions of the syzygy with their characteristic progametic nuclei as well as the 467 sporocysts require clarifications. This point is also important for Filipodium trophozoites 
468 where numerous microvilli from 1.6-10 $\mu \mathrm{m}$ long and about $0.15 \mu \mathrm{m}$ in diameter were 469 clearly described in TEM (Hoshide and Todd 1996).

All archigregarines are intestinal parasites of Annelida belonging to the clade

471 Sedentaria except one Selenidium metchnikovi reported in Hemichordata (Léger and 472 Duboscq 1917). In contrast, many lecudinids are intestinal parasites of the clade Errantia 473 from Annelida (Schrével and Desportes 2013). This separation between archigregarines and 474 marine lecudinid eugregarines is probably related to the different modes of living of their 475 hosts. For instance, lecudinids are adapted to the errant and predatory life of Errantia while archigregarines are adapted to sedentary life of Sedentaria with microphage species living 477 below stones, or as tube builders or ingesting sediment as the representatives of the family 478 Spionidae or surface deposit feeders with head appendages (Sabellidae, Sabellariidae). 479 Evolutionary history of Annelida is still poorly understood as the classic morphological 480 cladistic analysis with a monophyletic Polychaeta (Rouse and Fauchald 1997) was 481 challenged in the light of the recent molecular evidences. Today, Polychaeta are inferred to 482 be paraphyletic with the inclusion of the Clitella (earthworms) and the non-segmented taxa 483 Echiura and Sipunculida (Struck et al. 2011). Complexity of the phylogeny of Selenidium 484 species may reflect the one of their hosts. The true-Selenidium lineage within the 485 Selenidiidae family likely forms the core of archigregarines while the two other distant 486 lineages infecting respectively the Sipunculids and Terebellids orders, could be considered 487 as related Selenidium-like lineages. These results, deduced from molecular phylogeny 488 analyses need to be confirmed at the biological and cellular levels but are crucial since they 489 open new trends in evolutionary history among Apicomplexa.

The enigmatic Veloxidium leptosynaptae, initially placed within archigregarines 491 after phylogenetic analyses (Wakeman and Leander 2012) was later included within 492 lecudinids and urosporids (Wakeman et al. 2014). In our phylogenetic studies, it also 493 groups with lecudinids and urosporids with strong supports (Fig. 12).

Apicoplasts, Conoid, MTOC and Rhoptries are Major Cell Structures in the 496 Evolution of Apicomplexa

497 Gregarines represent interesting models to investigate the evolution from free-living 498 flagellated alveolates status, likely photosynthetic, to obligatory parasites among 499 Apicomplexa.

500 In archigregarines, the presence of an apicoplast remains an open question. Presence 501 of a functional plastid is reported in Chromera, a free-living photosynthetic relative to 
Apicomplexa (Lim and McFadden 2010). The apicoplast, a non-photosynthetic plastid of

503 red algae origin, is well documented in some Apicomplexa species such as Plasmodium,

504 Toxoplasma, Eimeria, Babesia, Theileria. This relict plastid is limited by four membranes

505 indicating its secondary endosymbiont origin. In the eugregarine Gregarina niphandrodes,

506 the apicoplast seems to be absent (Toso and Omoto 2007). Here in S. pendula, apicoplast-

507 like organelles are regularly observed in trophozoites at the ultrastructural level.

508 Interestingly Ray (1930) reported the visualization of a dark spot stained with Heidenhain's

509 haematoxylin, associated to each merozoite nucleus in $S$. mesnili parasitizing the

510 polychaete Myxicola infundibulum. Such an observation at the light microscopy level was

511 also observed by TEM, revealing the presence of an organelle with four membranes close

512 to the anterior part of each S. hollandei merozoite (Schrével 1971b).

513 The apical phagotrophy in the free-living predators of alveolates, with open conoid

514 and rhoptries, may be at the origin of the anchoring device of archigregarines like

515 Selenidium, characterized by their mucron and the myzocytosis function. The conoid of $S$.

516 pendula, similar to that of S. hollandei (Schrével 1968) and S. orientale (Simdyanov and

517 Kuvardina 2007), is conserved in large trophozoites and appears similar to the conoid of 518 sporozoites from eugregarines Stylocephalus africanus (Desportes 1969) and 519 Ascogregarina (Lankesteria) culicis (Sheffield et al. 1971). Among Conoidasida, the 520 conoid of $T$. gondii is the most investigated at the structural and molecular levels, with the 521 construction of unique coma-shaped tubulin sheets to form a spiral cone-shaped structure 522 (Hu and Murray 2002; Hu et al. 2006). As S. pendula is the archigregarine type species and 523 an early branching Apicomplexa, its conoid appears a good model to study the transition 524 between Apicomplexa with closed conoid and free-living alveolate ancestors with open conoid, as found in the early branching dinoflagellates as Colpodella (Brugerolle 2002;

526 Leander et al. 2003) or Psammosa pacifica (Okamoto and Keeling 2014).

Recently, the hypothesis of molecular links between Apicomplexa and algal ancestors was suggested with the demonstration of similar components in the apical

530 supported by the localization of striated fiber assemblies (Francia et al. 2012) and SAS-6 531 proteins (de Leon et al. 2013). T. gondii striated fiber assemblins (TgSFA2 and TgSFA3) 532 proteins whose orthologs are found in the rootlet associated with the basal bodies from 533 green algae, polymerize into a dynamic fiber that emerges from the centrosomes 534 immediately after their duplication (Francia et al. 2012). Genetic experiments showed that 535 the two proteins TgSFA2 and 3 play an essential role in the cell division of the $T$. gondii 
536 since cytokinesis is blocked in their absence. This Tg SFA fiber thus provides a robust

537 spatial and temporal organizer for the parasite cell division. Also, Francia et al. (2012)

538 indicated that other comparable SFA fibers were observed in previous ultrastructural

539 studies on Eimeria (Dubremetz 1973, 1975) and Plasmodium (Schrével et al. 2008).

540 The SAS-6 protein is well known in the centriolar biogenesis of eukaryotes from

541 protists to vertebrates (Leidel et al. 2005; van Breugel et al. 2011). This protein was

542 described in the centrocone during T. gondii cryptomitosis (de Leon et al. 2013). In

543 addition a novel SAS-6 like (SAS-6L) protein family that shares an N-terminal domain

544 with SAS-6 but without the coiled-coil tails was localized above the $T$. gondii conoid (de

545 Leon et al. 2013). Genomic analyses showed that SAS-6L is an ancient protein found in

546 diverse eukaryotic lineages: Trypanosoma, Leishmania, ciliates and Apicomplexa (Hodges

547 et al. 2010; de Leon et al. 2013). In Trypanosoma brucei trypomastigotes, the Tb SAS-6L

548 was observed near the basis of the flagellum, consistent with the basal body location. In $T$.

549 gondii, the Tb SAS-6L antibody labelled the apex of tachyzoites, and after conoid extrusion

550 triggered by ionomycin treatment, it labelled the tip of the "true" conoid. The SAS-6L and

551 SAS-6 antibodies did not colocalize in $T$. gondii, the former one labelling the centriole and

552 the latter one labelling the conoid tip (de Leon et al. 2013).

Complex connections between the "pseudoconoid" or "incomplete conoid" and the flagellar apparatus were also shown, by conventional TEM and 3D reconstruction, in the apical complex of Psammosa pacifica, a predator relative of apicomplexans and early dinoflagellates (Okamoto and Keeling 2014).

The MTOC of the centrocones of $S$. pendula appears as a disc similar to that observed in other eugregarines such as L. tuzetae where 9 singlets could be detected in favourable TEM sections (Kuriyama et al. 2005). From these MTOC discs, microtubules radiated to form a cone involved in the cup-shaped invaginations of the nuclear envelope.

561 The continuity of these MTOC during the life cycle could be in agreement with a 562 centriolar-like structure since a $9+0$ axonemal pattern is observed in $S$. pendula male 563 gamete (Fig.11B). The question of the subpellicular microtubule biogenesis is not clear.

564 The conoid is not, by itself, the MTOC since it is absent in the zoites of Hematosporida and 565 Piroplasmida. The two polar rings, observed at the apex of the Eimeria or Plasmodium zoites were proposed as the MTOC sites generating the subpellicular microtubules (Russel and Burns 1984), but these two polar rings were not observed in S. pendula. The imc

568 dilatation at the border of the proximal opening of the conoid could fulfil this function (Fig.

569 4). The exceptional accumulation of microtubule bundles in the anterior part of the mucron, 
570 before the regular subpellicular microtubule sets of the epicytic bulges (Fig. 2D), is in

571 agreement with the strong labelling of S. melongena apex with fluorescent anti-alpha 572 tubulin (Wakeman et al. 2014). Biogenesis of these abundant microtubule bundles needs 573 further analysis.

574 Rhoptries are characteristic of the apicomplexan zoites and also of the Selenidiidae 575 trophozoites (Schrével et al. 2013 for a review). Interestingly, presence of numerous 576 intracytoplasmic thread-like bodies described by Ray (1930) in the apex of different 577 Selenidium trophozoites was visualized after iron haematoxylin staining (Heidenhain's 578 haematoxylin). By their sizes reaching 8-12 $\mu \mathrm{m}$ depending on the Selenidium species and 579 their localization, these thread-like structures could correspond to the rhoptries described 580 from TEM such as in S. pendula (Fig. 5A), S. hollandei (Schrével 1968) and S. orientale 581 (Symdyanov and Kurvidina 2007). Ray (1930) considered these thread-like structures as 582 one of the morphological characters of each Selenidium species, however the abundance of 583 rhoptries detected in TEM is in fact a general character for archigregarines (Schrével et al.

584 2013, for review). Biological functions of many apicomplexan rhoptry proteins remain 585 largely unknown. In Plasmodium and Toxoplasma, the most investigated apicomplexans at 586 the molecular level, there is growing evidence to suggest that the rhoptry neck proteins are 587 predominantly involved in host-cell adhesion with some sharing evolutionary origins 588 among apicomplexans. In contrast, the rhoptry bulb proteins appear mainly genus specific, 589 suggesting that they evolved secondarily to become highly specific to their host cells 590 (Counihan et al. 2013). In S. pendula, food vacuole membranes may have arised from 591 numerous rhoptries localized within the apex. A strong membrane trafficking is expected to 592 produce the large and abundant food vacuoles observed during myzocytosis (Fig. 4A). 593 Therefore Selenidium rhoptry proteins could play a role in producing intracellular food 594 vacuole in contrast to Apicomplexa with an intracellular development, where the rhoptry 595 proteins seem involved in the parasitophorous vacuole elaboration such as in Plasmodium 596 and Toxoplasma.

598 Archigregarines and Eugregarines: Two Early Branching Lineages Among 599 Apicomplexa

600 The transition from the free-living alveolates to apicomplexan parasites was supported by 601 comparative ultrastructural studies and molecular phylogeny analyses of basal lineages, 602 such as dinoflagellates (together with perkinsids) and apicomplexans (including 603 colpodellids) (Leander and Keeling 2003). The myzocytosis is the most plesiomorphic 
604 features of apicomplexans with archigregarines having a closed conoid (Schrével 1968, 605 1971b), and colpodellids the sister lineage of Apicomplexa with an open conoid (Kuvardina 606 et al. 2002). In perkinsids, representing the earliest diverging sister lineage of 607 dinoflagellates (Saldarriaga et al. 2003), an open conoid is also observed (Perkins 1996). 608 These three types of parasites also share rhoptry-like organelles and, together with their 609 phylogenetic positions, they confidently infer that a common ancestor of apicomplexans 610 and dinoflagellates had an apical complex involved in the acquisition of nutrients from the 611 cytoplasm of prey cells (Leander and Keeling 2003).

Among the high diversity of gregarines in invertebrates, Polychaeta, an animal class

613 known to be present at the Cambrian biodiversity explosion and to represent one of the 614 earliest Bilateria organisms (De Rosa et al. 2005; Schrével and Desportes 2013), is well 615 infected by gregarines. This situation supports the evolutionary prelude of marine 616 gregarines to the apicomplexan radiation (Leander 2007). The initial archigregarine 617 radiation is supported by the "hypersporozoite" cell organization of the trophozoite, the 618 myzocytosis and the pendular or rolling motility (Schrével 1971; Schrével and Desportes 619 2015). The subsequent eugregarine radiation, with an adaptation to the intestinal biome and 620 an extracellular development, could have emerged from intestinal lecudinid gregarines. 621 Here, their cell cortex is quite different from archigregarines by the presence of numerous 622 epicytic folds, without the regular sets of subpellicular microtubules but with a 623 sophisticated distribution of 12-nm filaments, apical rippled dense structures at the top of 624 the folds (Schrével et al. 1983; Vivier 1968). Their gliding motility depends upon an actin625 myosin system but the molecular mechanochemical properties are far from being understood (Heintzelman 2004; Valigurová et al. 2013). The myzocytosis, similar to the archigregarine model, is not observed in these marine eugregarines: their nutrition process is realized through a bulbous attachment apparatus usually designated by mucron.

The gregarine colonization of the coelom in invertebrate hosts by transmigration of 630 the sporozoites through the intestinal epithelium and a coelomic development reveal 631 additional adaptations of eugregarines to their host environment. These adaptations are a 632 significant evolutionary step of marine gregarines as suggested by Leander (2007), and 633 represent an antithesis to any notion of "primitiveness". One of the best evidence is the 634 unique adaptation of the coelomic eugregarine Diplauxis hatti to its host Perinereis 635 cultrifera where a strict synchronization is observed between the maturation of the 636 polychaete gametes and the sexual phases (gamogony and sporogony) of the parasite 637 (Prensier et al. 2008). This example illustrates how gregarines are well adapted to their host 
638 environment. For instance, $D$. hatti is adapted to $P$. cultrifera but cannot invade other

639 Nereidae host as Hedistes (Nereis) diversicolor nor Nereis pelagica. The extreme

640 adaptation of some gregarines to their host environments could explain some unexpected

641 situations such as the reduction observed from the canonical 9+2 flagellar pattern, in the 642 male gametes, with a 9+0 pattern in S. pendula (this study), 6+0 in L. tuzetae (Schrével and 643 Besse 1975) and $3+0$ in $D$. hatti (Prensier et al. 1980). The 9+0 pattern of Selenidium, close 644 to the $9+2$ normality, may be correlated to a fertilization phase lasting about 1 hour in a 1645 day sexual phase (gamogony and sporogony), the $6+0$ pattern of L. tuzetae, may result from 646 a fertilization realized in few hours within a cyst, during a 3 days sexual phase of the 647 Lecudina life cycle (Schrével 1969). More impressively, the $3+0$ pattern in D. hatti could 648 have been selected over evolution because of the fertilization step lasting only few hours in 649 a highly extended complete life cycle, lasting 2.5 years (Prensier et al. 2008). Such 650 evolutionary proposal, suggesting that each gregarine develops its own programme 651 according to its environment is in agreement with the notion of regressive evolution in 652 microorganisms proposed by Lwoff (1944). This type of regressive evolution could 653 probably continue with other coelomic gregarines with the disappearance of the flagellum 654 in male gametes of Gonospora species as suggested from histology studies (Schrével 1963; 655 Trégouboff 1918). Expression of the own program of each coelomic eugregarines is also 656 observed with the variations in their epicytic cell surface transformations with digits, 657 surface swelling in Pterospora, microvillosities in Diplauxis or the development of 658 peristaltic motility instead of gliding, sometimes a pendular motility is observed in young 659 trophozoite and peristaltic motility during the fast growing period of the same trophozoite 660 as observed in D. hatti (see Schrével et al. 2013 for a review).

\section{Conclusion}

665 Molecular phylogenetic analyses of archigregarines demonstrate that S. pendula, the type 666 species of archigregarines, belongs to a lineage with a large number of Selenidium parasites 667 of Spionidae, Sabellaridae, Sabellidae, Cirratulidae families of the Sedentaria Polychaeta. 668 All these Selenidium exhibit similar biological characters such as the cell cortex with a 669 plasma membrane, imc (inner-membrane-complex) and subpellicular microtubules, the apical complex with a conoid, the myzocytosis with large food vacuoles and abundance of 
671 large rhoptry organelles, the nuclear multiplication during the syzygy and the early gamonts. Two other Selenidium-like lineages are observed in the Terebellidae and

673 Sipunculida where the sexual characters are not available at this time. Such a status

674 underlines an adaptation of the family Selenidiidae to their host families and this first early 675 evolutive lineage could correspond to the transition step between the free-living flagellated 676 alveolates and the Apicomplexa, before the diversification of the marine eugregarines without the typical myzocytosis realized through the conoid but with a gliding motility.

\section{Methods}

Preparation of annelids and gregarines: Isolates of the gregarine Selenidium pendula Giard, 1884 type species, were collected from the intestine of the polychaete worm

684 Scolelepis squamata (O. F. Müller, 1806) (previously named Nerine cirratulus, Delle 685 Chiaje, 1831) on the French coast of the English Channel at the "Station Biologique de 686 Roscoff', in 2007 then again in 2012. Isolates of the gregarines Selenidium hollandei 687 Vivier and Schrével, 1966, Lecudina pellucida (Mingazzini, 1891) type species and 688 different isolates of L. tuzetae Schrével, 1963 were also collected from the intestines of polychaete worms from the same area, in 2007, 2012, 2013 and 2014 (Table 2).

After washing in seawater, each collected worm was kept, at the laboratory temperature, in a separate Petri dish. The medium (seawater) was changed daily. For longterm conservation, the collected worms were rinsed with $0.22 \mu \mathrm{m}$ filtered seawater and stored at $4{ }^{\circ} \mathrm{C}$. In order to collect Selenidium pendula Giard, 1884, the anterior part of the Scololelepis squamata worms, with a yellow color, was discarded since the parasites were always absent, then the worms were cut transversally in series of segments of about 1 to 1.5 cm of length. To collect S. hollandei, L. pellucida and L. tuzetae, a similar type of microdissection was performed from their corresponding hosts, under a classic binocular microscope, in order to expose the intestinal epithelial surface to the seawater. In addition, and only in the case of L. tuzetae, cysts excreted with feces were collected from the Petri dishes of individually kept Neanthes (Nereis) diversicolor (O. F. Müller, 1776).

701 Trophozoites of $S$. pendula, attached to the intestine, were easily detected, in spite of their 702 rather small sizes (usually $150-180 \mu \mathrm{m} \times 30-35 \mu \mathrm{m}$ ), by their white color - contrasting to the characteristic green color of the intestinal epithelium of the worm - and by their active 
pendular movements. In highly infected Scolelepis squamata, trophozoites and sexual stages of $S$. pendula (syzygies and young cysts) were also collected in Petri dishes, among the gametes released from hosts during the dissection. S. hollandei trophozoites were easily observed in host epithelium by their very active rolling movements, immediately after sectioning the post abdominal segment of their hosts, Sabellaria alveolata Linnaeus, 1767.

Electron microscopy: For transmission electron microscopy (TEM), intestinal epithelial tissues of Scolelepis squamata highly infected with trophozoites of $S$. pendula were collected and fixed in $5 \%(\mathrm{v} / \mathrm{v})$ glutaraldehyde in $100-150 \mathrm{mM}$ phosphate or $0.2 \mathrm{M}$ cacodylate buffer ( $\mathrm{pH} 7.3$ ), at $4{ }^{\circ} \mathrm{C}$, for 6 to 12 hours. The syzygy and gametocytes of $S$. pendula, not attached to the epithelium, were collected directly in the seawater from the

714 Petri dishes and fixed in the same conditions. After washing either in the same buffer or in 715 buffer containing $0.3 \mathrm{M}$ sucrose, the samples were post-fixed with $1 \%(\mathrm{w} / \mathrm{v}) \mathrm{OsO}_{4}$ in the 716 same buffer for $1 \mathrm{hr}$, then processed through standard dehydration, infiltration, and 717 embedding procedures, in Epon or Araldite mixtures, with the corresponding solvents (i.e. 718 propylene oxide or acetone respectively), at room temperature. The blocks were thin sectioned, collected on grids and stained with saturated uranyl acetate in $50 \%(\mathrm{v} / \mathrm{v})$ ethanol for 1-3 min then in lead citrate. Sections were observed with a Hitachi HU 11 E electron microscopy (Hitachi Ltd, Japan) or a JEOL 1010 TEM.

For SEM, the intestines were open along the axis of the polychaete, and the body parts highly infected by $S$. pendula were carefully washed in $0.22 \mu \mathrm{m}$-filtered seawater before fixation in glutaraldehyde as done above for TEM. After the post fixation in $1 \%$ $\mathrm{OsO}_{4}$ in $0.2 \mathrm{M}$ cacodylate buffer, specimens were dehydrated in a graded series of acetone, critical point-dried in liquid $\mathrm{CO}_{2}$ and coated with gold. The samples were examined in a JEOL JSM-7401F FE SEM.

DNA isolation and sequencing: For the LG isolates ( $S$. pendula LG, S. hollandei LG, L. pellucida LG Table 1), groups of 50-70 isolated trophozoites were washed at least 730 three times in $0.22 \mu \mathrm{m}$-filtered seawater and DNA was extracted from individual parasites 731 using a modified GITC (Guanidinium isothiocyanate) protocol (Chomczynski and Sacchi 732 2006). Individuals were placed in $50 \mu \mathrm{l}$ of the GITC extraction buffer and crushed using an 733 adjusted micro-pilon (Kimble Chase ${ }^{\circledR}$ ). Tubes were incubated at $72{ }^{\circ} \mathrm{C}$ for $20 \mathrm{~min}$. Next, 734 one volume of cold isopropanol was added at $-20{ }^{\circ} \mathrm{C}$ overnight for DNA precipitation. The 735 following day, samples were centrifuged $\left(20,000 \mathrm{~g}, 15 \mathrm{~min}\right.$ at $\left.4{ }^{\circ} \mathrm{C}\right)$ and supernatants 736 removed. The DNA pellet was cleaned using 70\% ethanol $(100 \mu \mathrm{l})$, followed by a last 737 centrifugation $(20,000 \mathrm{~g}, 10 \mathrm{~min})$. Supernatant was removed and the DNA pellet was 
hydrated into $20 \mu \mathrm{l}$ of sterile distilled water and stored at $-20{ }^{\circ} \mathrm{C}$. For $S$. pendula IF, a group of $\sim 50-70$ isolated trophozoites were washed at least three times in $0.22 \mu \mathrm{m}$ filtered seawater and genomic DNA was isolated by using a phenol-chloroform extraction procedure as previously described for Plasmodium falciparum (Florent et al. 2000), and the purified DNA pellet was rehydrated into $20 \mu \mathrm{l}$ of sterile distilled water and stored at $-20{ }^{\circ} \mathrm{C}$.

For L. tuzetae Roscoff 2012 IF462, DNA was isolated by using the phenolchloroform extraction procedure described above, from 2 cysts, collected from the feces of a single Neanthes (Nereis) diversicolor (O. F. Müller, 1776) host individually kept in a Petri dish. The purified DNA pellet was rehydrated into $20 \mu \mathrm{l}$ of sterile distilled water and was stored at $-20{ }^{\circ} \mathrm{C}$. Finally, for the 4 remaining L. tuzetae Roscoff, DNA extractions were performed using MasterPure ${ }^{\mathrm{TM}}$ Complete DNA and RNA Purification kit (Epicentre, Illumina Inc. USA) following supplier's recommendations for Cell Samples manipulations, with minor modifications, from respectively 7 cysts (IF131), 50 cysts (IF171 and IF172) and 30 cysts (IF181). Briefly, each group of cysts was isolated from the feces of a single $N$. diversicolor host individually kept in a Petri dish, from which each cyst was then extensively washed, one by one, in three successive drops of $0.22 \mu \mathrm{m}$ filtered seawater supplemented with antibiotics penicillin $(100 \mathrm{U} / \mathrm{mL})$, streptomycin $(100 \mu \mathrm{g} / \mathrm{mL})$ and gentamycin $(50 \mu \mathrm{g} / \mathrm{mL})$ (Gibco, Life Technologies, USA) then pooled again. Then, isolated and washed cysts were submerged in $300 \mu \mathrm{L}$ Tissue-and-Cell lysis solution, submitted to five series of freezing (liquid nitrogen) and thawing $\left(37^{\circ} \mathrm{C}\right)$ before addition of Proteinase $\mathrm{K}$ then RNAse A and, after sample processing as recommended, isolated DNA pellets were rehydrated in $35 \mu \mathrm{TE}$ (10 mM Tris-pH 7.5 and 1mM EDTA) prior to subsequent storage at $-20{ }^{\circ} \mathrm{C}$.

These DNA extraction products were then used as templates in various series of PCR amplifications, in order to amplify the SSU rRNA gene of these gregarines, then sequenced using the Sanger sequencing methodology.

LG samples. The PCR mix (15 $\mu$ l final volume) contained $1-6 \mu$ of the DNA extract, $330 \mu \mathrm{M}$ of each deoxynucleoside triphosphate (dNTP), $2.5 \mathrm{mM}$ of $\mathrm{MgCl}_{2}, 1.25 \mathrm{U}$ of GoTaq ${ }^{\circledR}$ DNA polymerase (Promega Corporation), $0.17 \mu \mathrm{M}$ of both primers, $1 \times$ of buffer (Promega Corporation). The PCR cycle, run in an automated thermocycler (GeneAmp®PCR System 9700, Applied Biosystem, USA), was programmed to give an initial denaturating step at $95{ }^{\circ} \mathrm{C}$ for $5 \mathrm{~min}, 35$ cycles of denaturating at $95{ }^{\circ} \mathrm{C}$ for $1 \mathrm{~min}$, annealing at $55^{\circ} \mathrm{C}$ for $45 \mathrm{~s}$ and extension at $72{ }^{\circ} \mathrm{C}$ for $1 \mathrm{~min} 15 \mathrm{~s}$, and a final extension step at $72{ }^{\circ} \mathrm{C}$ for $7 \mathrm{~min}$. PCR products were cloned into a TOPO TA cloning kit (Invitrogen ${ }^{\circledR}$ ), 
following manufacturer's recommendations. Inserts inside white colonies were screened by PCR (same procedure as before). Positive PCR products were purified (ExoSAP-IT® For PCR Product Clean-Up, USB $\left.{ }^{\circledR}\right)$ and sequenced using the Big Dye Terminator Cycle Sequencing Kit version 3.0 (PE Biosystems ${ }^{\circledR}$ ) and an ABI PRISM model 377 (version 3.3) automated sequencer with specific internal primers.

The list of primers used for both PCR amplifications and Sanger sequencing is provided in the table of the Supplementary data 6 .

IF samples. PCR amplifications were done using Hot firepol DNA polymerase as recommended (Solis BioDyne, Estonia), in a $50 \mu 1$ final volume supplemented with $2 \mathrm{mM}$ $\mathrm{MgCl}_{2}, 200 \mu \mathrm{M}$ each dNTPs and $200 \mathrm{nM}$ forward (P4+T or WL1) and reverse (EukP3) primers (Supplementary Material 6) and $1 \mu 1$ of isolated gregarine DNAs. PCR cycles, run in an automated thermocycler (GeneAmp ${ }^{\circledR P C R}$ System 9700, Applied Biosystem, USA), were programmed to give an initial denaturation step at $95{ }^{\circ} \mathrm{C}$ for $4 \mathrm{~min}, 30$ cycles of denaturation at $95{ }^{\circ} \mathrm{C}$ for $30 \mathrm{~s}$, annealing at $51^{\circ} \mathrm{C}$ for $30 \mathrm{~s}$ and extension at $72{ }^{\circ} \mathrm{C}$ for $2 \mathrm{~min}$, and a final extension step at $72{ }^{\circ} \mathrm{C}$ for $7 \mathrm{~min}$. PCR products were purified using Illustra ${ }^{\mathrm{TM}}$ GFX $^{\mathrm{TM}}$ PCR DNA and Gel Band Purification kit (GE Healthcare, France) and were cloned into pGEM $^{\circledR}-\mathrm{T}$ Easy vector (Promega, Madison WI, USA) using supplier's recommendations. DNA sequences were obtained from positive clones selected by PCR using T7 and Sp6 universal primers flanking the pGEM ${ }^{\circledR}$-T Easy vector cloning site, using T7, Sp6 and internal primers such as LWA1, LWA3, PIF3F and PIF3R (Table 6), by the Sanger method (Beckman Coulter Genomics, Takeley, UK). Raw were edited using the BioEdit 7.1.3.0 program (Hall 1999) and assembled by using MEGA6 (Tamura et al. 2013)

Phylogenetic analyses: SSU rDNA sequences from nine Selenium and Lecudina species were aligned to 106 rDNA sequences from diverse eukaryotes, mostly corresponding to representatives of Alveolata with one Rhizaria as outgroup. Sequences were aligned using the online version of MAFFT version 7 (http://mafft.cbrc.jp/alignment/server/ Katosh and Toh 2010), using the secondary structure of RNA (Q-INS-I option) and further refined manually taking as a reference the secondary structure of $T$. gondii small subunit rRNA (Gagnon et al. 1996). Ambiguously aligned positions were manually removed which yielded a confident alignment of 1350 positions. A GTR substitution model with gamma-distributed rate variation across sites was suggested as the best-fit model by JModeltest V2.1.3 (Darriba et al. 2012). Accordingly, a Bayesian phylogenetic tree was constructed with MrBayes v.3.2.3 (Ronquist et al. 2012) using lset $n s t=6$ rates $=$ Invgamma Ngammacat $=4$ parameters. Four simultaneous Monte 
806 Carlo Markov chains were run from random trees for a total of 13,000,000 generations in two

807 parallel runs. A tree was sampled every 1000 generation and $25 \%$ of the trees were discarded as

808 "burn-in". A consensus tree was constructed from the post-burn-in trees and posterior

809 probabilities were calculated in MrBayes. Maximum Likelihood analyses were performed with

810 MEGA 6.06 (Tamura et al. 2013) using the GTR+G+I model. Bootstraps were estimated from

8111,000 replicates.

812 The phylogenetic tree for the Selenidiidae lineage from polychate annelids (Fig. 13)

813 was contructed using the same alignment but for a subset of 20 sequences; all position

814 containing gaps and missing data were eliminated; there were a total of 1,416 positions in

815 the final dataset. Maximum Likelihood analyses were performed with MEGA 6.06 (Tamura

816 et al. 2013) using the GTR+G+I model. Bootstraps were estimated from 1,000 replicates.

817 Estimate of evolutionary divergence between sequences: Evolutionary

818 divergence between sequences was computed by using the MEGA 6.06 (Tamura et al.

819 2013) using a subset of sequences extracted from the main phylogenetic alignment. For the

820 analysis of the Selenidiidae lineage (Supplementary Material 4) the analysis involved 33

821 nucleotide sequences for 16 distinct species, there were a total of 2088 positions in the final

822 dataset and all positions containing gaps and missing data were eliminated.

823

824

825 Acknowledgements

827 Many thanks to Dr Isabelle Desportes (MNHN) for her fruitful comments, Dr Marc

828 Dellinger (MNHN) for help in primer design and Dr Marc Gèze (MNHN) for imaging on

829 the MNHN-CEMIM Platform. The careful illustrations of the figures were realized by

830 Doanh Baccam (MNHN). This study was supported by ECO-NET Project 2131QM (Égide,

831 France), PHC-Barrende projects 24663ND (2011-2012) and 31266SL (2014-2015),

832 Interdisciplinary Programs of the MNHN (ATM-Microorganismes, ATM-Emergence des

833 clades, des biotes et des cultures) and by the French governmental ANR under ANR-10-

834 LABX-0003 BCDiv, ANR-11-IDEX-0004-0 and the ANR-14-CE02-0007-01 (HAPAR).

835 AV was funded by the Czech Science Foundation project No. GBP505/12/G112 (ECIP),

836 and her travel expenses were supported by projects MEB021127 and 7AMB14FR013 from

837 the Ministry of Education, Youth and Sports of the Czech Republic. 


\section{References}

Boothroyd JC, Dubremetz JF (2008) Kiss and split: the dual roles of Toxoplasma rhoptries. Nat Rev Microbiol 6:79-88

\section{Bradley PJ, Ward C, Cheng SJ, Alexander DL, Coller S, Coombs GH, Dunn JD,} Ferguson DJ, Sanderson SJ, Wastling JM, Boothroyd JC (2005) Proteomic analysis of rhoptry organelles reveals many novel constituents for host-parasite interactions in Toxoplasma gondii. J Biol Chem 280:34245-34258

Brasil L (1907) Recherches sur le cycle évolutif des Selenidiidae, Grégarines parasites d'Annélides polychètes. I. La schizogonie et la croissance des gamétocytes chez Selenidium caulleryi n. sp. Arch Protistenkd 16:370-397

Brugerolle G (2002) Colpodella vorax: ultrastructure, predation, life-cycle, mitosis, and phylogenetic relationships. Eur J Protistol 38:113-125

Caullery M, Mesnil F (1899) Sur quelques parasites internes des Annélides. I. Grégarines nématoides des annélides. Trav Stat Zool Wimereux 7:80-99

Caullery M, Mesnil F (1900) Sur un mode particulier de division nucléaire chez les Grégarines. Arch Anat Microsc 3:146-167

Chomczynski P. and Sacchi, N (2006) The single-step method of RNA isolation by acid guanidinium thiocyanate-phenol-chloroform extraction: twenty-something years on. Nat Protoc 1:581-585

\section{Counihan NA, Kalanon M, Coppel RL, de Koning-Ward TF (2013) Plasmodium} rhoptry proteins: why order is important. Trends Parasitol 29:228-236

Darriba D, Taboada GL, Doallo R, Posada D (2012) jModeltest 2: more models, new heuristics and parallel computing. Nat Methods 9:772-772

de Leon JC, Scheumann N, Beatty W, Beck JR, Tran JQ, Yau C, Bradley PJ, Gull K, Wickstead B, Morisette NS (2013) A SAS-6-like protein suggests that the Trypanosoma conoid complex evolved from flagellar components. Eukaryot Cell 12:1009-1015

De Rosa R, Prud'homme B, Balavoine G (2005) Caudal and even-skipped in the annelid Platynereis dumerilii and the ancestry of the posterior growth. Evol Dev 7:574-587

Desportes I, Schrével J (2013, eds) The Gregarines: The Early Branching Apicomplexa. Brill, Leiden, $781 \mathrm{p}$

Dubremetz JF (1973) Etude ultrastructurale de la mitose schizogonique chez la Coccidie Eimeria necatrix (Johnson, 1930). J Ultrastruct Res 42:354-376

Dubremetz JF (1975) Genesis of merozoites in the coccidia, Eimeria necatrix: Ultrastructural study. J Protozool 22:71-84 

Grellier P (2000) Cloning of Plasmodium falciparum protein disulfide isomerase homologue by affinity purification using the antiplasmodial inhibitor inhibitor 1,4-bis $\{3$ [N-(cyclohexyl methyl)amino]propyl \} piperazine. FEBS Lett 484:246-252

Francia ME, Jordan CN, Patel JD, Sheiner L, Demerly JL, Fellows JD, de Leon JC, Morrissette NS, Dubremetz JF, Striepen B (2012) Cell division in apicomplexan parasites is organized by a homolog of the striated rootlet fiber of algal flagella. PLoS Biol 10:e1001444

Francia ME, Striepen B (2014) Cell division in apicomplexan parasites. Nat Rev Microbiol 12:125-136

\section{Gagnon S, Bourbeau D, Levesque RC (1996) Secondary structures and features of the} 18S, 5.8S and 26S ribosomal RNAs from the apicomplexan parasite Toxoplasma gondii. Gene 173:129-35

Goldstein SF, Schrével J (1982) Microtubules and cell motility. SFRS, France, CERIMES, www.cerimes.education.fr

Gunderson J, Small EB (1986) Selenidium fallax n.sp. (Protozoa, Apicomplexa) from the sipunculid Phascolosoma agassizii Kerferstein 1867. J Parasitol 72:107-110

Hall TA (1999) BioEdit: a user-friendly biological sequence alignment editor and analysis program for Windows 96/98NT. Nucleic Acids Symp Ser 41:95-98

\section{Harper JD, Thuet J, Lechtreck KF, Hardham AR (2009) Proteins related to green algal} striated fiber assemblin are present in stramenopiles and alveolates. Protoplasma 236:97101

Heintzelman MB (2004) Actin and myosin in Gregarina polymorpha. Cell Motil Cytoskeleton 58:83-95

Hodges ME, Scheumann N, Wickstead B, Langdale JA, Gull K (2010) Reconstructing the evolutionary history of the centriole from protein components. J Cell Biol 123:14071413

Hoshide H, Todd KS (1996) The fine structure of cell surface and hair-like projections of Filipodium ozakii Hukui. Acta Protozool 35:309-315

Hu K, Roos DS, Murray JM (2002) A novel polymer of tubulin forms the conoid of Toxoplasma gondii. J Cell Biol 156:1039-1050

Hu K, Johnson J, Fraunholz M, Surajajjala S, DiLullo C, Yates J, Rossn DS, Murray JM (2006) Cytoskeletal Components of an Invasion Machine-The Apical Complex of Toxoplasma gondii. PLoS Pathogens 2(2):e13:121-138 
907 Katoh K, Toh H (2010) Parallelization of the MAFFT multiple sequence alignment 908 program. Bioinformatics 26:1899-1900

909 Kuriyama R, Besse C, Geze M, Omoto CK, Schrével J (2005) Dynamic organization of 910 microtubules and microtubule-organizing centers during the sexual phase of a parasitic 911 protozoan, Lecudina tuzetae (Gregarine, Apicomplexa). Cell Motil Cytoskeleton 62:195$912 \quad 209$

913 Kuvardina ON, Leander BS, Aleshin VV, Myl'nikov AP, Keeling PJ, Simdyanov TG 914 (2002) The phylogeny of colpodellids (Alveolata) using small subunit rRNA genes 915 sequences suggests there are the free-living group to apicomplexans. J Eukaryot Microbiol $916 \quad 49: 498-504$

917 Leander BS (2006) Ultrastructure of the archigregarine Selenidium vivax (Apicomplexa)-A 918 dynamic parasite of sipunculid worms (host: Phascolosoma agassizii). Mar Biol Res 2:178919190

920 Leander BS (2007a) Marine gregarines: evolutionary prelude to the apicomplexan 921 radiation? Trends Parasitol 24:60-7

922 Leander BS (2007b) Molecular phylogeny and ultrastructure of Selenidium serpulae 923 (Apicomplexa, Archigregarinia) from the calcareous tubeworm Serpula vermicularis 924 (Annelida, Polychaeta, Sabellida). Zool Scripta 36:213-22

925 Leander BS, Keeling PJ (2003) Morphostasis in alveolate evolution. Trends Ecol Evol $926 \quad \mathbf{1 8 : 3 9 5 - 4 0 4}$

927 Leander BS, Harper JT, Keeling PJ (2003) Molecular phylogeny and surface 928 morphology of marine aseptate gregarines (Apicomplexa): Selenidium spp. and Lecudina 929 spp. J Parasitol 89:1191-205

930 Leander BS, Kuvardina ON, Aleshin VV, Mylnikov AP, Keeling PJ (2003) Molecular 931 phylogeny and surface morphology of Colpodella edax (Alveolata): insights into the 932 phagotrophic ancestry of apicomplexans. J Eukaryot Microbiol 50:334-340

933 Léger L, Duboscq O (1917) Sporozoaires de Glossobalanus minutus Kow. Eimeria 934 epidermica n. sp.; Eimeria beauchampi n. sp.; Selenidium metchnikowi n. sp. Ann Inst 935 Pasteur 31:60-74

936 Leidel S, Delattre M, Cerutti L, Baumer K, Gonczi P (2005) SAS-6 defines a protein 937 family required for centrosome duplication in C. elegans and human cells. Nat Cell Biol $938 \quad 7: 115-125$

939 Lim L, McFadden GI (2010) The evolution, metabolism anf functions of the apicoplast.

940 Philos Trans Royal Soc B 365:749-763 
941 Lwoff A (1944) L'évolution physiologique. Etude des pertes de fonction chez les

942 microorganismes. Hermann Publ, Paris, $308 \mathrm{p}$

943 Macgregor HC, Thomasson PA (1965) The fine structure of two archigregarines,

944 Selenidium fallax and Ditrypanocystis cirratuli. J Protozool 12:438-443

945 Mignot JP (1966) Ultrastructure des Eugléniens. Etude de la cuticule chez différentes 946 espèces. Protistologica 2:51-117

947 Misof B, Liu S, Meusemann K, et al. (2014) Phylogenomics resolves the timing and 948 pattern of insect evolution. Science 346:763-767

949 Molon-Noblot S, Desportes I (1980) Etude ultrastructurale des mitoses gamogoniques de 950 la Grégarine Grebnickiella gracilis Gr. parasite de la scolopendre Scolopendra cingulata L.

951 Considérations sur les mitoses schizogoniques des Sporozoaires (Apicomplexa).

952 Protistologica 16:395-411

953 Nei M, Kumar S (2000) Molecular Evolution and Phylogenetics. Oxford University Press, 954 New York, $333 \mathrm{p}$

955 Okamoto N, Keeling PJ (2014) The 3D structure of the apical complex and association 956 with the flagellar apparatus revealed by serial TEM tomography in Psammosa pacifica, a 957 distant relative of the Apicomplexa. PLoS ONE 9(1):e84653

958 Perkins FO (1996) The structure of Perkinsus marinus (Mackin, Owen and Collier, 1950) 959 Levine, 1978 with comments on the taxonomy and phylogeny of Perkinsus spp. J Shellfish 960 Res 15:67-87

961 Prensier G, Vivier E, Goldstein S, Schrével J (1980) Motile flagellum with a "3 + 0" 962 ultrastructure. Science 207:1493-4

963 Prensier G, Dubremetz JF, Schrével J (2008) The unique adaptation of the life cycle of 964 the coelomic gregarine Diplauxis hatti to its host Perinereis cultrifera (Annelida, 965 Polychaeta): an experimental and ultrastructural study. J Eukaryot Microbiol 55:541-53

966 Ray HN (1930) Studies on some sporozoa in polychaete worms.I. Gregarines of the genus 967 Selenidium. Parasitology 22:370-398

968 Reed N (1933) Sporogony in Selenidium mesnili Brasil, a sporozoan parasite of Myxicola 969 infundibulum Mont. Parasitology 25:402-409

970 Ronquist F, Teslenko M, van der Mark P, Ayres DL, Darling A, Höhna S, Larget B, 971 Liu L, Suchard MA, Huelsenbeck JP (2012) MrBayes 3.2: efficient Bayesian 972 phylogenetic inference and model choice across a large model space. Syst Biol 61:539-42

973 Rouse GW, Fauchald K (1997) Cladistics and Polychaetes. Zool Scripta 26:139-204 
974 Rueckert S, Leander BS (2009) Molecular phylogeny and surface morphology of marine

975 archigregarines (Apicomplexa), Selenidium spp., Filipodium phascolosomae n. sp., and 976 Platyproteum n. g. and comb. from North-Eastern pacific peanut worms (Sipuncula). J 977 Eukaryot Microbiol 56:428-439

978 Russell DG, Burns RG (1984) The polar ring of coccidian sporozoite: a unique 979 microtubule-organizing centre. J Cell Sci 65:197-207

980 Saldarriaga JF, McEwan ML, Fast NM, Taylor FJ, Keeling PJ (2003) Multiple protein 981 phylogenies show that Oxyrrhis marina and Perkinsus marinus are early branches of 982 dinoflagellate lineage. Int J Syst Evol Microbiol 53:355-365

983 Santos JM, Lebrun M, Daher W, Soldati D, Dubremetz JF (2009) Apicomplexa 984 cytoskeleton and motors: key regulators in morphogenesis, cell division, transport and 985 motility. Int J Parasitol 39:153-162

986 Schrével J (1963) Contribution à l'étude de trois Grégarines parasites d'Annélides 987 Polychètes: Lecudina elongata Mingazzini1891; Lecudina tuzetae Schrével 1963; 988 Gonospora varia Léger 1892. Arch Zool Exp Gén 104:125-142

989 Schrével J (1966) Cycle de Selenidium pendula Giard 1884, Grégarine parasite de Nerine 990 cirratulus Delle Chiaje (Annélide Polychète). Protistologica 2:31-34

991 Schrével J (1968) L'ultrastructure de la région antérieure de la grégarine Selenidium et son 992 intérêt pour l'étude de la nutrition chez les Sporozoaires. J Microsc Paris 7:391-410

993 Schrével J (1969) Recherches sur le cycle des Lecudinidae grégarines parasites 994 d'Annélides Polychètes. Protistologica 5:561-588

995 Schrével J (1970) Contribution à l'étude à l'étude des Selenidiidae parasites d'Annélides 996 Polychètes: I. Cycles biologiques. Protistologica 6:389-426

997 Schrével J (1971a) Contribution à l'étude à l'étude des Selenidiidae parasites d'Annélides 998 Polychètes:II. Ultrastructure de quelques trophozoites. Protistologica 7:101-130

999 Schrével J (1971b) Observations biologiques et ultrastructurales sur les Selenidiidae et 1000 leurs conséquences sur la systématique des Grégarinomorphes. J Protozool 18:448-470

1001 Schrével J, Besse C (1975) Un type flagellaire fonctionel de base 6+0. J Cell Biol 66:492$1002 \quad 507$

1003 Schrével J, Desportes I (2013) Introduction: Gregarines among Apicomlexa. Chapter 1, 7100424 in Desportes I, Schrével J (eds) The Gregarines. The Early Branching Apicomplexa. 1005 Brill, Leiden, pp 7-24

1006 Schrével J, Desportes I (2015) Gregarines. In Mehlhorn H (ed). Encyclopedia of 1007 Parasitology , 4 th edn, Springer, Berlin, Heidelberg, pp 1-47 
1008 Schrével J, Caigneaux E, Gros D, Philippe M (1983) The three cortical membranes of

1009 the gregarines. I. Ultrastructural organization of Gregarina blaberae. J Cell Sci 61:151-74

1010 Schrével J, Desportes I, Goldstein S, Kuriyama R, Prensier G, Vávra J (2013) Biology

1011 of Gregarines and their Host-parasite Interactions. Chapter 2, 25-195 in Desportes I,

1012 Schrével J (eds) The Gregarines. The Early Branching Apicomplexa. Brill, Leiden, pp 251013195

1014 Schrével J, Asfaux-Foucher G, Hopkins JM, Vincent R, Bourgouin C, Prensier G,

1015 Bannister LH (2008) Vesicle trafficking during sporozoite development in Plasmodium

1016 berghei: ultrastructural evidence for a novel trafficking mechanism. Parasitology 135:1-12

1017 Sheffield HG, Garnham PCC, Shiroishi T (1971) The fine structure of the sporozoite of

1018 Lankesteria culicis. J. Protozool 18:98-105

1019 Simdyanov TG, Kuvardina ON (2007) Fine structure and putative feeding mechanism of 1020 the archigregarine Selenidium orientale (Apicomplexa:Gregarinomorpha). Eur J Protistol $1021 \quad$ 43:17-25

1022 Struck TH, Paul C, Hill N, Hartman S, Hösel C, Kube M, Lieb B, Meyer A, 1023 Tiedemann R, Purschke G, Bleidorn C (2011) Phylogenomic analyses unravel annelid 1024 evolution. Nature 471:95-98

1025 Tamura K, Stecher G, Peterson D, Filipski A, Kumar S (2013) MEGA6: Molecular 1026 Evolutionary Genetics Analysis Version 6.0. Mol Biol Evol 30:2725-2729

1027 Toso MA, Omoto CK (2007) Gregarina niphandrodes may lack both a plastid genome 1028 and organelle. J Eukaryot Microbiol 54:66-72

1029 Trégouboff G (1918) Etude monographique de Gonospora testiculi Treg., grégarine 1030 parasite du testicule de Cerithium vulgatum Brug. Arch Zool Exp Gén 57:471-509

1031 Tuzet O, Ormières R (1958) Selenidium flabelligerae n. sp. parasite de Flabelligera 1032 diplochaitos Otto (Annélide sédentaire). Ann Sci Nat Zool 13:71-76

1033 Valigurová A, Vaškovicová N, Musilová N, Schrével J (2013) The enigma of 1034 eugregarine epicytic folds: where the gliding motility originates? Frontiers Zool 10:57

1035 van Breugel M, Hirono M, Andreeva A, Yanagisawa HA, Yamaguchi S, Nakazawa Y, 1036 Morgner N, Petrovitch M, Ebong IO, Robinson CV, Johnson M, Veprintsev D, Zuber 1037 B (2011) Structures of SAS-6 suggest its organization in centrioles Science 331:1196-1199

1038 Vivier E (1967) Observations ultrastructurales sur l'enveloppe nucléaire et ses "pores" chez 1039 les Sporozoaires. J Microsc Paris 6:371-390

1040 Vivier E (1968) L'organisation ultrastructurale corticale de la grégarine Lecudina 1041 pellucida; ses rapports avec l'alimentation et la locomotion. J Protozool. 15:230-246 
1042 Vivier E, Schrével J (1964) Etude au microscope électronique d'une Grégarine du genre

1043 Selenidium parasite de Sabellaria alveolata L. J Microsc Paris 3:651-670

1044 Vivier E, Schrével J (1966) Les ultrastructures cytoplasmiques de Selenidium hollandei, n.

1045 sp., Grégarine parasite de Sabellaria alveolata L. J Microsc Paris 5:213-228

1046 Wakeman KC, Leander BS (2012) Molecular phylogeny of Pacific Archigregarines

1047 (Apicomplexa), including descriptions of Veloxidium leptosynaptae n. gen., n. sp., from the

1048 sea cucumber Leptosynapta clarki (Echinodermata), and two new species of Selenidium. J

1049 Eukaryot Microbiol 59:1-14

1050 Wakeman KC, Leander BS (2013) Molecular phylogeny of marine gregarine parasites

1051 (Apicomplexa) from tube-forming polychaetes (Sabellariidae, Cirratulidae and Serpulidae)

1052 including descriptions of two new species of Selenidium. J Eukaryot Microbiol 60:514-525

1053 Wakeman KC, Heintzelman MB, Leander BS (2014) Comparative ultrastructure and

1054 molecular phylogeny of Selenidium melongena n. sp. and S. terebellae Ray 1930

1055 demonstrate niche partitioning in marine gregarine parasites (Apicomplexa). Protist 1056 165:493-511

1057 
1059 Figure 1. Scanning and transmission electron microscopy of Selenidium pendula 1060 trophozoites fixed to the intestine of the polychaete worm Scolelepis squamata (A-B.). 1061 Abbreviations: bulge (B), dense granule (DG), food vacuole (FV), groove (G), intestinal 1062 epithelium (IE), mucron (MU), rhoptry (R). A. SEM micrograph of trophozoites with their 1063 apical region inserted into the intestinal epithelium, exhibiting on this face about 18 1064 longitudinal bulges separated by grooves. The long filamentous structures covering the 1065 intestinal epithelium correspond to ciliary structures (arrows). B. Longitudinal TEM section of a trophozoite with the apical end designated as mucron containing a food vacuole and numerous rhoptries. In the intestinal epithelium, the trophozoite preferentially anchors to the host cells enriched in dense granules having mucous secretions.

Figure 2. Apex of the Selenidium pendula trophozoite (A-D). Abbreviations: bulge (B), conoid (Co), food vacuole (FV), groove (G), intestinal epithelium (IE), microneme (mn), microtubules (mt), microvilli (mv), mucron (MU), rhoptry (R). A. SEM micrograph of the apex surface showing that bulges and grooves of the epicyte start from a regular mammiliform area corresponding to the external surface of the mucron. Small folds

1075 (arrows) are observed on the bulges located on the internal curvature of the cell B. SEM 1076 micrograph of intestinal epithelium after the detachment of a mucron, with small microvilli on the periphery, a small hole in the subcentral position (white arrow) and the long ciliary structures (black arrow). C. TEM micrograph of a median longitudinal section of the apex with several food vacuoles that enter via the conoid and are surrounded by an accumulation of rhoptries and micronemes.

D. TEM longitudinal section of the apical region (=

1081 trophozoite apex with numerous micronemes and rhoptries) revealing that the subpellicular 1082 microtubule bundles start before the differentiation of the epicytic bulges of the cell 1083 surface.

1085 Figure 3. Cell surface and cortex of Selenidium pendula trophozoite (A-F). Abbreviations: 1086 bulge (B), groove (G), inner membrane complex (imc), microneme (mn), microtubules 1087 (mt), mitochondrion (M), myelin-like structure (st myel), plasma membrane (pm), pore (p), 1088 rhoptry (R), vesicle (ves). A. SEM view of the cell surface with the apertures of pores along 1089 the grooves (arrows). B-F. TEM cross sections of the cortex with the plasma membrane, 1090 the dilated inner membrane complex and the subpellicular microtubules under the epicytic 
1091 bulges (C). In cross section, each microtubule is surrounded by a white hexagonal area.

1092 Ectoplasmic organelles in the grooves, connected to the cortical membranes via the imc,

1093

1094

1095 1096

1097

1098

1099

1100

1101

1102

1103

1104

1105

1106

1107

1108

1109

1110

1111

1112

1113

1114

1115

1116 Figure 6. Rhoptries, micronemes and Golgi apparatus (A-D). Abbreviations: amylopectin 1117 granule (am), Golgi apparatus (Go), intrareticular granule (ig), microneme (mn), 1118 mitochondrion (M), rhoptry (R). A-B. TEM cross sections of an accumulation of rhoptries 1119 and micronemes within the cytoplasm. The micronemes appear as long-necked bottles, the 1120 necks appear as dense rings in cross sections (white thick arrow in B). C-D. Golgi 1121 apparatus and mitochondrion occur close to the micronemes; the cis-region of the Golgi 1122 apparatus usually contains numerous intrareticular granules (D). contain lamellar structures (arrow in B) or dense material (white arrow in D). These organelles form an annular ring in cross section parallel to the cell surface (white arrow in E) corresponding to the cross section of a micropore or myelin-like structures $(F)$.

Figure 4. Conoid in the Selenidium pendula mucron (A-C). Abbreviations: dense granule (DG), conoid (Co), food vacuole (FV), food vacuole membrane (fvm), inner membrane complex (imc), host intestinal epithelium (IE), parasite plasma membrane (pm). A-B. Two longitudinal sections of the $S$. pendula mucron, showing the conoid structure and the opening, allowing a contact between the fvm and the host cell, visible in A. C. High magnification showing the 9 cross sections of the microtubular network forming the conoid.

Figure 5. Food vacuoles and rhoptries in the apex of the $S$. pendula trophozoite (A-B), and apicoplast-like organelles (C, D, E). Abbreviations: conoid (Co), food vacuole (FV), host intestinal epithelium (IE), microneme (mn), mitochondrion (M), fragmented food vacuoles similar to pinocytotic vesicles (pv), rhoptry (R). A. TEM cross section with the initial food vacuole passing through the conoid and the fragmented food vacuoles similar to the pinocytotic vesicles (pv) observed in S. hollandei (Schrével 1968). Numerous rhoptries are accumulated around these food vacuoles. B. Another cross section showing the irregular shapes of the initial food vacuole and the intravacuolar vesicles. (C-E). Apicoplast-like organelles, characterized by the presence of four membranes morphologically similar to the apicoplast of Toxoplasma and Plasmodium. 
1124 Figure 7. Nuclear area of Selenidium pendula trophozoite (A-E). Abbreviations: 1125 amylopectin granule (am), intrareticular granule (ig), microneme (mn), nuclear pores (np), 1126 nucleus $(\mathrm{N})$, nucleolus $(\mathrm{nu})$. A-B. TEM cross sections of the nucleus containing a spherical 1127 nucleolus (A) and surrounded by the regular fibrillar zone without organelles (white arrows 1128 in B). This fibrillar area is delimited by large vesicles of the rough endoplasmic reticular 1129 containing numerous granules and amylopectin granules. C. Tangential section of the 1130 nuclear envelope exhibits numerous pores. D. Occasional accumulation of micronemes can 1131 be observed near the nucleus. E. Higher magnification of the micronemes and intrareticular 1132 granules.

1134 Figure 8. Nuclear development during the syzygy of Selenidium pendula (A-D). 1135 Abbreviations: nucleus $(\mathrm{N})$, cyst wall $(\mathrm{CW})$. A-B. Fluorescence staining with DAPI 1136 showing nuclei in the median plane of each gamont corresponding to the initial position of 1137 the nucleus at the beginning of the syzygy stage. Their numbers are quite similar in the two gamonts and some bright spots are observed in some nuclei (B). C-D. TEM cross sections in an early cyst where the nuclei are accumulating in the central position of the gamont

1140 while the cell wall is not secreted $(\mathrm{C})$ and later after the secretion of the cyst wall where the 1141 nuclei migrate to the gamont periphery (D).

1143 Figure 9. Centrocones and mitosis stages during the gametogenesis of Selenidium pendula 1144 (A-B). Abbreviations: centrocone (CC), chromatin (Ch), cyst wall (CW), dense layer (dl), 1145 filamentous layer (fl), nuclear envelope (en), mitochondrion (M), microtubule-organizing center (MTOC), microtubule (mt), nucleus $(\mathrm{N})$, vesicle type 1 (V1) and type 2 (V2). A.

1147 Early gametogenesis stage before the secretion of the gametocyst wall exhibiting 1148 centrocone where the microtubules radiate from the MTOC to the cupule of the nuclear 1149 envelope forming a truncated cone. The chromatin covers the inner face of the nuclear 1150 envelope and a dense accumulation is observed in the nucleus. B. A second centrocone 1151 migrating on the other side of the nucleus. No intranuclear spindle is observed, the 1152 chromatin is attached to the persistent nuclear envelope. Two types of vesicles are observed 1153 one with dense granules (V1) and a second one with filamentous material (V2). The 1154 gametocyst wall exhibits an external filamentous layer and an internal dense layer.

1156 Figure 10. Reorganisation of the cortical membranes in Selenidium pendula gamonts and 1157 ultrastructure of the gametocyst wall during the gametogenesis stage (A-D). Abbreviations: 
1158 gametocyst wall (CW), dense layer (dl), epicytic folds (ef), filamentous layer (fl), inner 1159 membrane complex (imc), plasma membrane (pm), vesicle type 1 (V1) and type 2 (V2). A-

1160 C. TEM cross sections of the gamont's periphery where the epicytic folds are disorganized 1161 with dissociation of the inner member complex under the plasma membrane. The wall of 1162 the gametocyst exhibits a filamentous external layer and a more homogenous internal layer; 1163 the vesicles of type 2 are probably involved in the cyst wall construction. D. Higher 1164 magnification of the cyst wall with large amount of filaments attached to the surface of the 1165 internal homogenous layer.

1167 Figure 11. Gamonts with gametes and young sporocysts after the fertilization (A-C). 1168 Abbreviations: amylopectin granule (am), axoneme (Ax), gametocyst wall (CW), dense 1169 granule (DG), dense layer (dl), filamentous layer (fl), mitochondrion (M), nucleus (N), 1170 sporocyst wall (SW). A. Gametocyst wall after the formation of the gametes exhibits a third 1171 layer with more dense material under the two layers observed in more early gamont stages 1172 (Figure 12). Residual amylopectin and dense granules are observed between the gametes 1173 and the gametocyst wall. B. Cross sections of flagellar axonemes indicate a male gamete 1174 (B) and two serial sections are of a 9+0 pattern. C. After the fertilization process the young 1175 sporocysts are surrounded by a thin wall covered by very small spines.

1177 Figure 12. Maximum Likelihood (ML) tree inferred on an alignment of 115 small subunit 1178 (SSU) rDNA sequences corresponding to 9 Selenidium and Lecudina species from this 1179 current study (highlighted in grey boxes) and 106 sequences from diverse eukaryotes 1180 corresponding mostly to representatives of Alveolata with one Rhizaria as outgroup. The 1181 Maximum Likelihood method is based on the General Time Reversible $+\mathrm{G}+\mathrm{I}$ model (Nei 1182 and Kumar 2000). The tree is drawn to scale, with branch lengths measured in the number 1183 of substitutions per site. A branch was shortened by a multiple (3) of the length of 1184 substitutions/site scale bar. There were a total of 1153 positions in the final dataset. ML 1185 evolutionary analyses were conducted in MEGA6 (Tamura et al. 2013). Numbers at the 1186 branches denote ML bootstrap percentage (first value). Bayesian posterior probabilities are 1187 also indicated (second value). Black dots on branches denote bootstrap percentages above $118899 \%$ and Bayesian posterior probabilities superior to 0.97 .

1190 Figure 13. Molecular phylogenetic analysis by Maximum Likelihood method of 1191 Selenidiidae lineage retrieved from polychaete annelids (host families in bold black). 
1192 The evolutionary history was inferred by using the Maximum Likelihood method based on 1193 the General Time Reversible model (Nei and Kumar 2000). The tree with the highest log 1194 likelihood (-5446.5092) is shown. A discrete Gamma distribution was used to model 1195 evolutionary rate differences among sites (5 categories with gamma parameter $=0.2711$ ). 1196 The rate variation model allowed for some sites to be evolutionarily invariable $(+\mathrm{I})$, $119739.8364 \%$ sites). The tree is drawn to scale, with branch lengths measured in the number of 1198 substitutions per site. Novel sequences are highlighted in grey boxes. 
1199 Table 1. List of the SSU rDNA sequence numbers of archigregarines and Veloxidium

1200 initially included in this group and the references: 1 . This work; 2. Leander et al. 2003; 3.

1201 Leander et al. 2007; 4. Rueckert and Leander 2009; 5. Wakeman and Leander 2012; 6.

1202 Wakeman and Leander 2013; 7. Wakeman et al. 2014.

\begin{tabular}{|c|c|c|c|c|c|c|}
\hline Archigregarines & \begin{tabular}{|l} 
SSU rDNA \\
sequences
\end{tabular} & Ref. & Host & Infraclass & Order & Family \\
\hline $\begin{array}{l}\text { Selenidium } \\
\text { pendula } \mathrm{LG}\end{array}$ & LN901443 & 1 & $\begin{array}{l}\text { Scolelepis } \\
\text { squamata }\end{array}$ & Canalipalpata & Spionida & Spionidae \\
\hline $\begin{array}{l}\text { Selenidium } \\
\text { pendula } \mathrm{IF}\end{array}$ & LN901444 & 1 & $\begin{array}{l}\text { Scolelepis } \\
\text { squamata }\end{array}$ & Canalipalpata & Spionida & Spionidae \\
\hline $\begin{array}{l}\text { Selenidium } \\
\text { boccardiella }\end{array}$ & JN857969 & 5 & $\begin{array}{l}\text { Boccardiella } \\
\text { ligerica }\end{array}$ & Canalipalpata & Spionida & Spionidae \\
\hline $\begin{array}{l}\text { Selenidium } \\
\text { mesnili }\end{array}$ & JN857968 & 5 & $\begin{array}{l}\text { Myxicola } \\
\text { infundibulum }\end{array}$ & Canalipalpata & Sabellida & Sabellidae \\
\hline $\begin{array}{l}\text { Selenidium } \\
\text { hollandei }\end{array}$ & LN901445 & 1 & $\begin{array}{l}\text { Sabellaria } \\
\text { alveolata }\end{array}$ & Canalipalpata & Sabellida & Sabellariidae \\
\hline $\begin{array}{l}\text { Selenidium } \\
\text { neosabellariae }\end{array}$ & $\begin{array}{l}\text { KC110871 } \\
\text { KC110872 } \\
\text { KC110873 } \\
\end{array}$ & 6 & $\begin{array}{l}\text { Neosabellaria } \\
\text { cementarium }\end{array}$ & Canalipalpata & Sabellida & Sabellariidae \\
\hline $\begin{array}{l}\text { Selenidium } \\
\text { identhyrsae }\end{array}$ & JN857967 & 6 & $\begin{array}{l}\text { Idanthyrsus } \\
\text { saxicavus }\end{array}$ & Canalipalpata & Sabellida & Sabellariidae \\
\hline $\begin{array}{l}\text { Selenidium } \\
\text { serpulae }\end{array}$ & DQ683562 & 3 & $\begin{array}{l}\text { Serpula } \\
\text { vermicularis }\end{array}$ & Canalipalpata & Sabellida & Serpulidae \\
\hline $\begin{array}{l}\text { Selenidium } \\
\text { sensimae }\end{array}$ & $\begin{array}{l}\mathrm{KC} 110869 \\
\mathrm{KC} 110870 \\
\end{array}$ & 6 & \begin{tabular}{|l|}
$\begin{array}{l}\text { Spirobranchus } \\
\text { giganteus }\end{array}$ \\
\end{tabular} & Canalipalpata & Sabellida & Serpulidae \\
\hline Selenidium $\mathrm{Sp} 1$ & $\begin{array}{l}\mathrm{KC} 110863 \\
\mathrm{KC} 110866 \\
\mathrm{KC} 110867 \\
\end{array}$ & 6 & $\begin{array}{l}\text { Spirobranchus } \\
\text { giganteus }\end{array}$ & Canalipalpata & Sabellida & Serpulidae \\
\hline Selenidium $\mathrm{Sp} 2$ & $\begin{array}{l}\text { KC110864 } \\
\text { KC110865 } \\
\text { KC110868 } \\
\end{array}$ & 6 & $\begin{array}{l}\text { Spirobranchus } \\
\text { giganteus }\end{array}$ & Canalipalpata & Sabellida & Serpulidae \\
\hline $\begin{array}{l}\text { Selenidium } \\
\text { terebellae }\end{array}$ & AY196709 & 2 & Thelepus sp, & Canalipalpata & Terebellida & Theleponidae \\
\hline $\begin{array}{l}\text { Selenidium } \\
\text { terebellae }\end{array}$ & $\begin{array}{l}\text { KC890803 } \\
\text { KC890804 } \\
\text { KC890805 } \\
\text { KC890806 }\end{array}$ & 7 & $\begin{array}{l}\text { Thelepus } \\
\text { japonica }\end{array}$ & Canalipalpata & Terebellida & Theleponidae \\
\hline $\begin{array}{l}\text { Selenidium } \\
\text { melongena }\end{array}$ & \begin{tabular}{|l|} 
KC890799 \\
KC890800 \\
KC890801 \\
KC890802
\end{tabular} & 7 & $\begin{array}{l}\text { Thelepus } \\
\text { japonica }\end{array}$ & Canalipalpata & Terebellida & Terebellinae \\
\hline $\begin{array}{l}\text { Selenidium cf } \\
\text { echinatum }\end{array}$ & $\begin{array}{l}\mathrm{KC} 110874 \\
\mathrm{KC} 110875 \\
\end{array}$ & 6 & $\begin{array}{l}\text { Dodecaceria } \\
\text { concarum }\end{array}$ & Canalipalpata & Terebellida & Cirratulidae \\
\hline $\begin{array}{l}\text { Selenidium } \\
\text { vivax }\end{array}$ & AF236097 & 2 & \begin{tabular}{|l} 
Phascolosoma \\
agassizii
\end{tabular} & Sipunculida & Phascolosimida & Phascolosomatidae \\
\hline $\begin{array}{l}\text { Platyproteum } \\
\text { vivax }\end{array}$ & AY 196708 & 4 & $\begin{array}{l}\text { Phascolosoma } \\
\text { agassizii }\end{array}$ & Sipunculida & Phascolosimida & Phascolosomatidae \\
\hline $\begin{array}{l}\text { Filipodium } \\
\text { phascolosoma }\end{array}$ & FJ832163 & 4 & $\begin{array}{l}\text { Phascolosoma } \\
\text { agassizii }\end{array}$ & Sipunculida & Phascolosimida & Phascolosomatidae \\
\hline $\begin{array}{l}\text { Selenidium } \\
\text { pisinnus }\end{array}$ & FJ832162 & 4 & $\begin{array}{l}\text { Phascolosoma } \\
\text { agassizii }\end{array}$ & Sipunculida & Phascolosimida & Phascolosomatidae \\
\hline $\begin{array}{l}\text { Selenidium } \\
\text { orientale }\end{array}$ & FJ832131 & 4 & $\begin{array}{l}\text { Themiste } \\
\text { pyroidea }\end{array}$ & Sipunculida & Golfingiida & \begin{tabular}{|l|} 
Veloxidium \\
leptosynaptae
\end{tabular} \\
\hline $\begin{array}{l}\text { Veloxidium } \\
\text { leptosynaptae }\end{array}$ & JN857966 & 5 & $\begin{array}{l}\text { Leptosynapta } \\
\text { clarki }\end{array}$ & Echinodermata & Apodida & Synaptidae \\
\hline
\end{tabular}


1204 Table 2. Summary of biological, geographical and molecular data, for original isolates in

1205 this study. The number of corresponding stages used for DNA preparations is indicated; T,

1206 trophozoite; C, cyst. Gene Accession numbers of the new sequences are available from the

1207 EMBL database.

1208

\begin{tabular}{|c|c|c|c|c|c|}
\hline Gregarine & Host & Location & $\begin{array}{l}\text { Isolate } \\
\text { names }\end{array}$ & Stage & $\begin{array}{c}\text { Gene } \\
\text { Access } \\
\text { number } \\
(18 \mathrm{~S})\end{array}$ \\
\hline $\begin{array}{l}\text { Selenidium } \\
\text { pendula } \text { Giard } \\
1884\end{array}$ & $\begin{array}{l}\text { Scolelepis } \\
\text { squamata (O. F. } \\
\text { Müller 1806) }\end{array}$ & $\begin{array}{l}\text { English Channel, } \\
\text { Roscoff, Aber, } \\
\text { Lat:4843’35.25'N, } \\
\text { Long:359'22.54”W. }\end{array}$ & $\begin{array}{l}\text { Selenidium } \\
\text { pendula } \mathrm{LG}\end{array}$ & $\begin{array}{c}50-70 \\
\mathrm{~T}\end{array}$ & LN901443 \\
\hline $\begin{array}{l}\text { Selenidium } \\
\text { pendula Giard } \\
1884\end{array}$ & $\begin{array}{l}\text { Scolelepis } \\
\text { squamata (O. F. } \\
\text { Müller 1806) }\end{array}$ & $\begin{array}{l}\text { English Channel, } \\
\text { Roscoff-Aber 2012, } \\
\text { Lat:4843’35.25”N, } \\
\text { Long:3॰59'22.54”W. }\end{array}$ & $\begin{array}{l}\text { Selenidium } \\
\text { pendula IF }\end{array}$ & $\begin{array}{c}50-70 \\
\mathrm{~T}\end{array}$ & LN901444 \\
\hline $\begin{array}{l}\text { Selenidium } \\
\text { hollandei } \\
\text { Vivier \& } \\
\text { Schrével } 1966 \\
\end{array}$ & $\begin{array}{l}\text { Sabellaria } \\
\text { alveolata } \\
\text { (Linnaeus 1767) }\end{array}$ & $\begin{array}{l}\text { English Channel, } \\
\text { Saint-Efflam-Ile Rouge } \\
\text { Lat:4840'57.96”N, } \\
\text { Long:3`35'32.52”'W. }\end{array}$ & $\begin{array}{l}\text { Selenidium } \\
\text { hollandei } \mathrm{LG}\end{array}$ & $\begin{array}{c}50-70 \\
\mathrm{~T}\end{array}$ & LN901445 \\
\hline $\begin{array}{l}\text { Lecudina } \\
\text { pellucida } \\
\text { (Mingazzini } \\
\text { 1891) }\end{array}$ & $\begin{array}{l}\text { Perinereis } \\
\text { cultrifera (Grübe } \\
\text { 1840) }\end{array}$ & 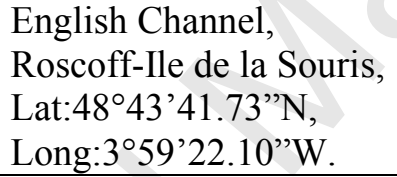 & $\begin{array}{l}\text { Lecudina } \\
\text { pellucida } \mathrm{LG}\end{array}$ & $\begin{array}{l}50-70 \\
\mathrm{~T}\end{array}$ & LN901442 \\
\hline $\begin{array}{l}\text { Lecudina } \\
\text { tuzetae } \\
\text { Schrével } 1963\end{array}$ & $\begin{array}{l}\text { Neanthes (Nereis) } \\
\text { diversicolor }(\mathrm{O} \text {. } \\
\text { F. Müller 1776) }\end{array}$ & 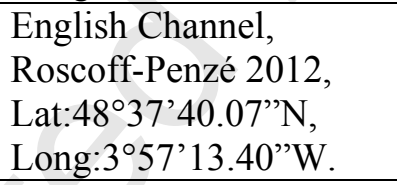 & \begin{tabular}{|l} 
Lecudina \\
tuzetae \\
Roscoff 2012 \\
IF132 \\
\end{tabular} & $7 \mathrm{C}$ & LN901446 \\
\hline $\begin{array}{l}\text { Lecudina } \\
\text { tuzetae } \\
\text { Schrével } 1963\end{array}$ & $\begin{array}{l}\text { Neanthes }(\text { Nereis) } \\
\text { diversicolor }(\mathrm{O} \text {. } \\
\text { F. Müller } 1776)\end{array}$ & $\begin{array}{l}\text { English Channel, } \\
\text { Roscoff-Penzé } 2013 \text {, } \\
\text { Lat:48`37’40,07’N, } \\
\text { Long:357'13.40”'W. }\end{array}$ & 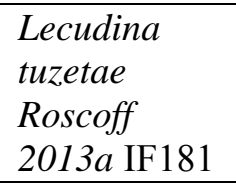 & $30 \mathrm{C}$ & LN901447 \\
\hline $\begin{array}{l}\text { Lecudina } \\
\text { tuzetae } \\
\text { Schrével } 1963\end{array}$ & $\begin{array}{l}\text { Neanthes (Nereis) } \\
\text { diversicolor (O. } \\
\text { F. Müller } 1776)\end{array}$ & 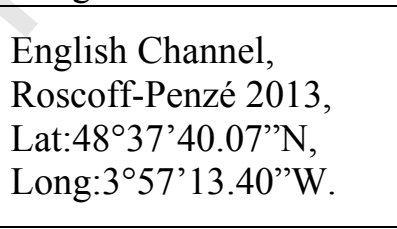 & $\begin{array}{l}\text { Lecudina } \\
\text { tuzetae } \\
\text { Roscoff } \\
2013 b \\
\text { IF462 } \\
\end{array}$ & $2 \mathrm{C}$ & LN901448 \\
\hline $\begin{array}{l}\text { Lecudina } \\
\text { tuzetae } \\
\text { Schrével } 1963\end{array}$ & $\begin{array}{l}\text { Neanthes (Nereis) } \\
\text { diversicolor }(\mathrm{O} \text {. } \\
\text { F. Müller 1776) }\end{array}$ & 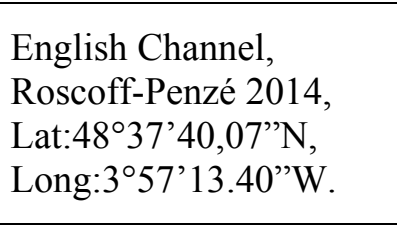 & $\begin{array}{l}\text { Lecudina } \\
\text { tuzetae } \\
\text { Roscoff } \\
2014 a \\
\text { IF171 } \\
\end{array}$ & $50 \mathrm{C}$ & LN901449 \\
\hline $\begin{array}{l}\text { Lecudina } \\
\text { tuzetae } \\
\text { Schrével } 1963\end{array}$ & $\begin{array}{l}\text { Neanthes } \\
\text { (Nereis) } \\
\text { diversicolor }(\mathrm{O} . \\
\text { F. Müller 1776) }\end{array}$ & 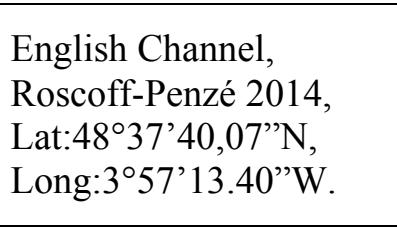 & $\begin{array}{l}\text { Lecudina } \\
\text { tuzetae } \\
\text { Roscoff } \\
2014 b \\
\text { IF172 }\end{array}$ & $50 \mathrm{C}$ & LN901450 \\
\hline
\end{tabular}

1209

1210 

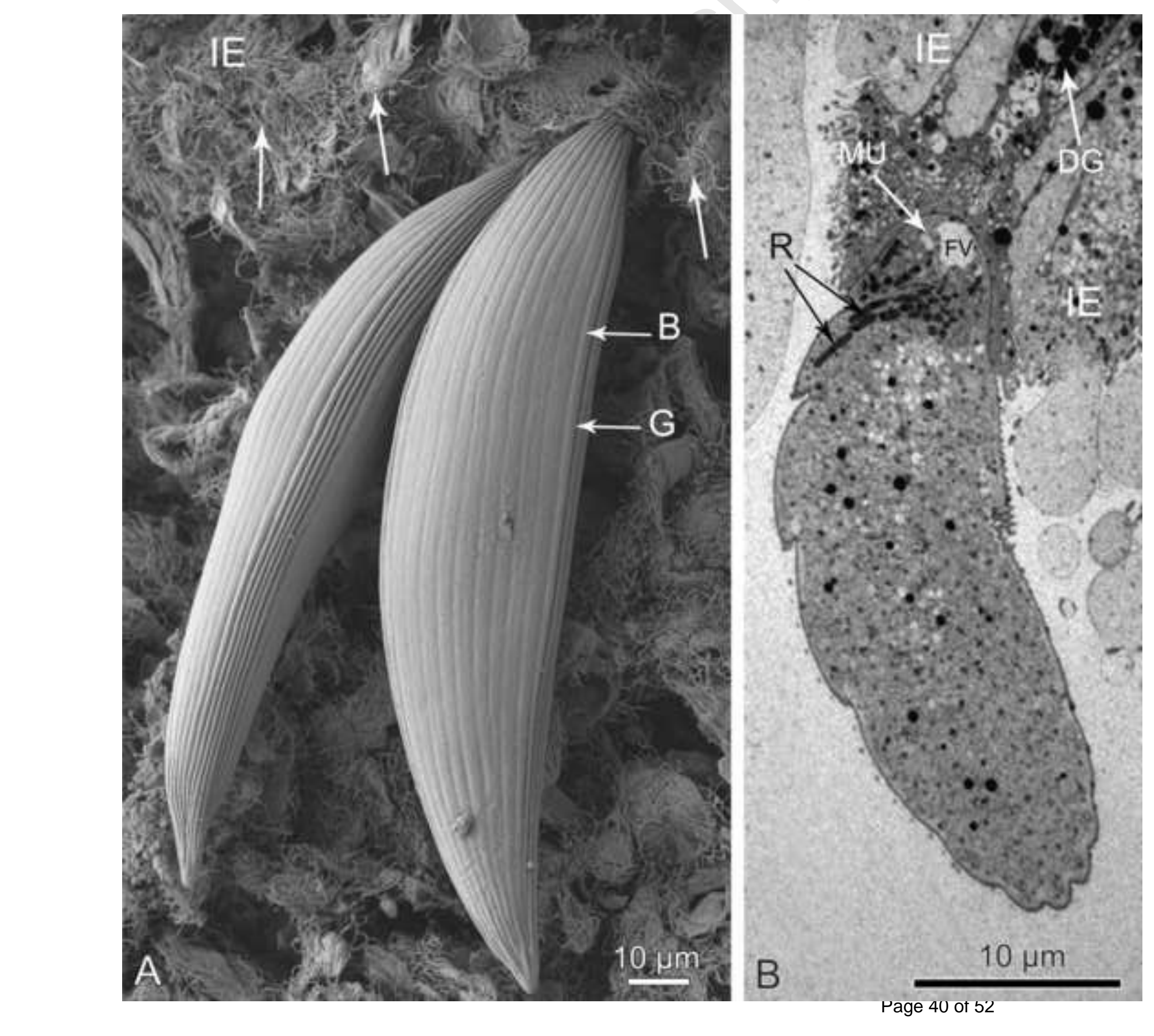


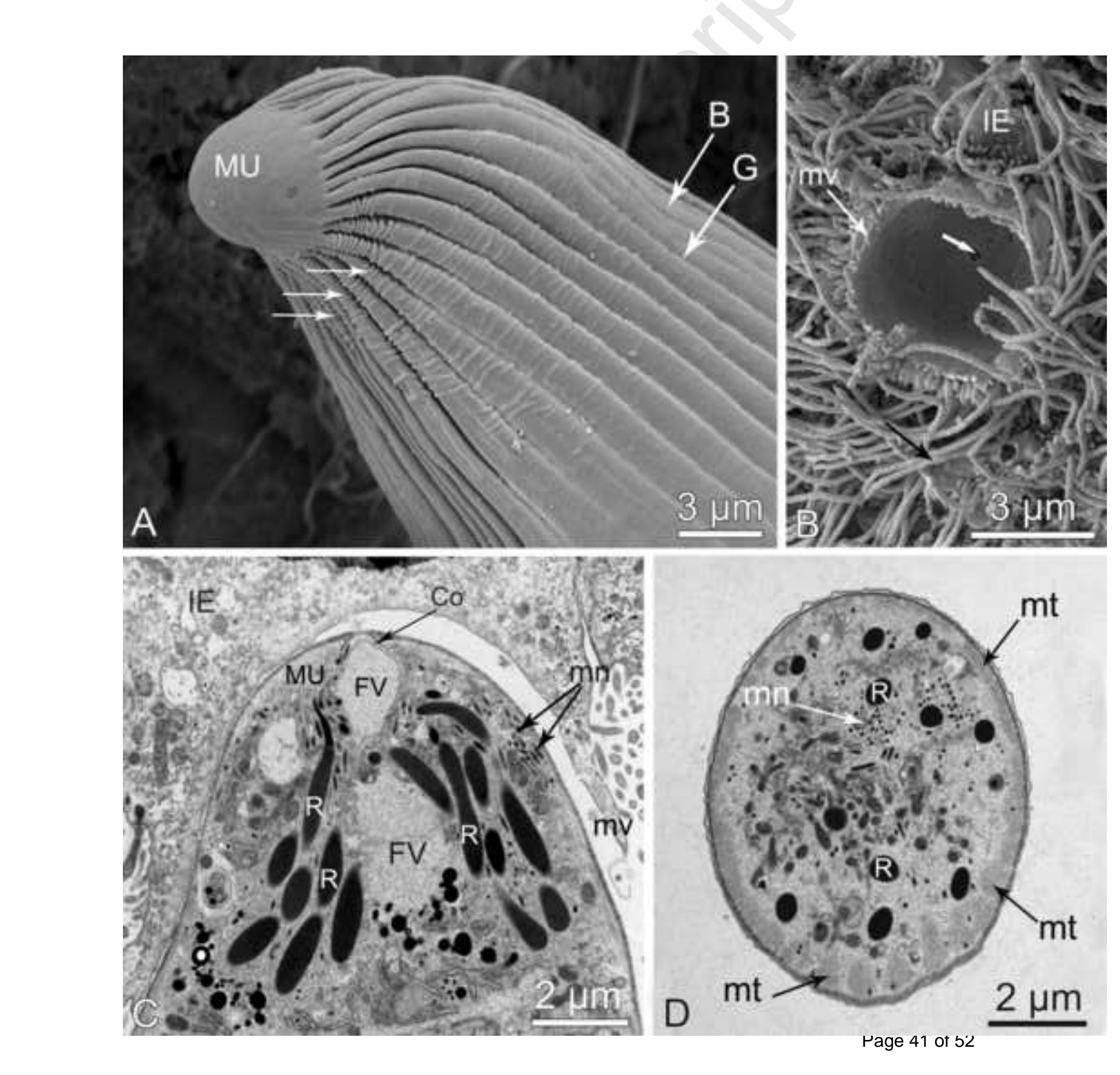

D

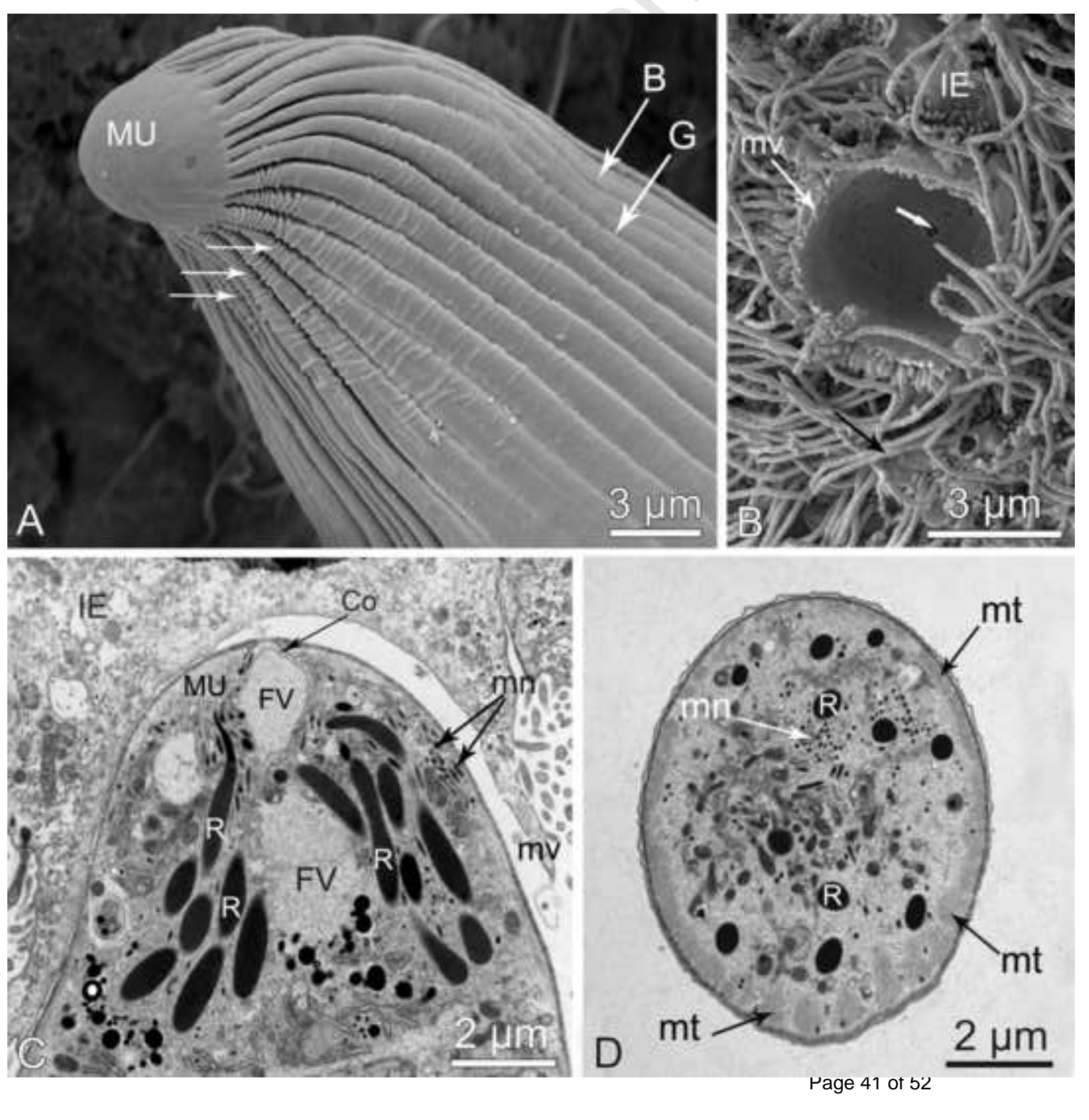

\section{. \\ .}

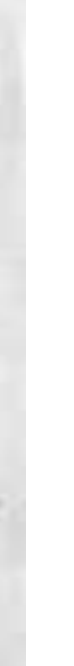

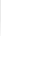

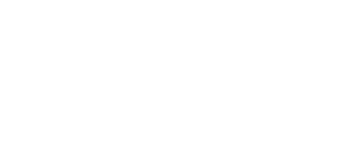




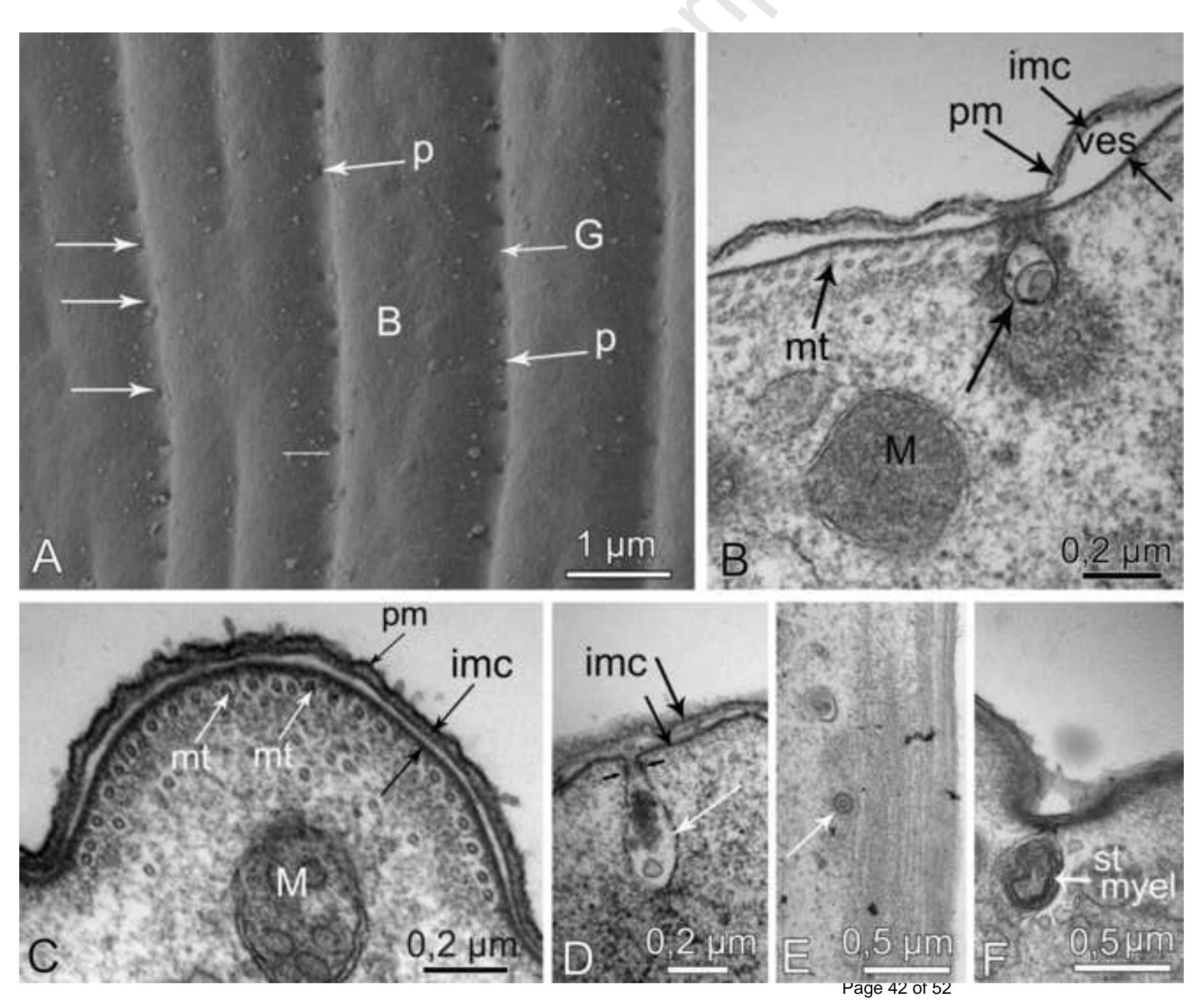

Figure

Figure 3
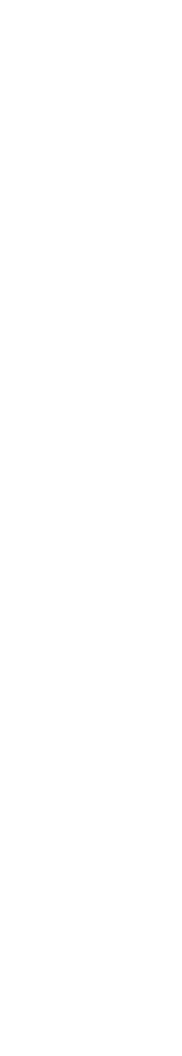

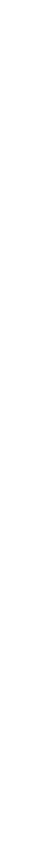

列
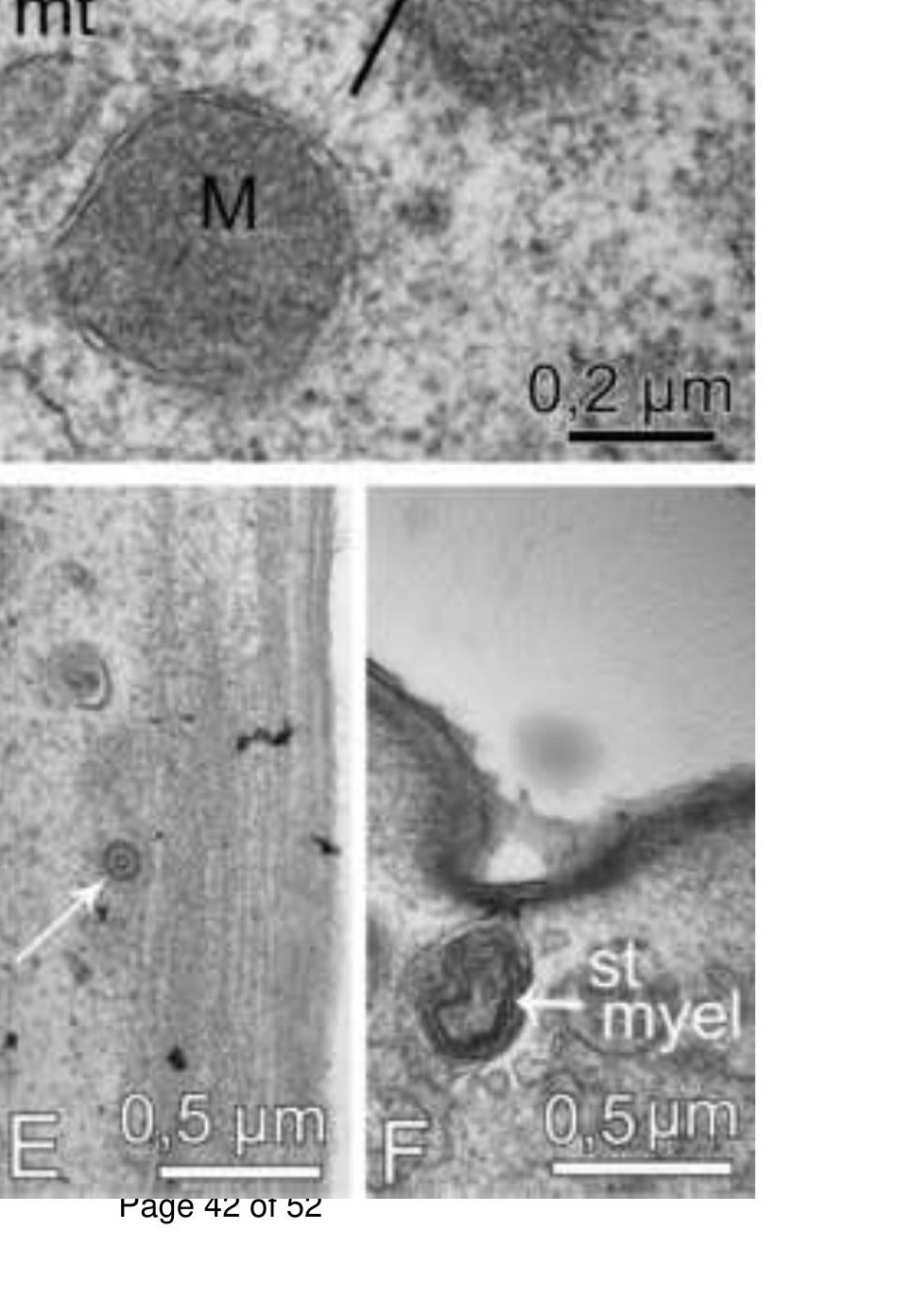

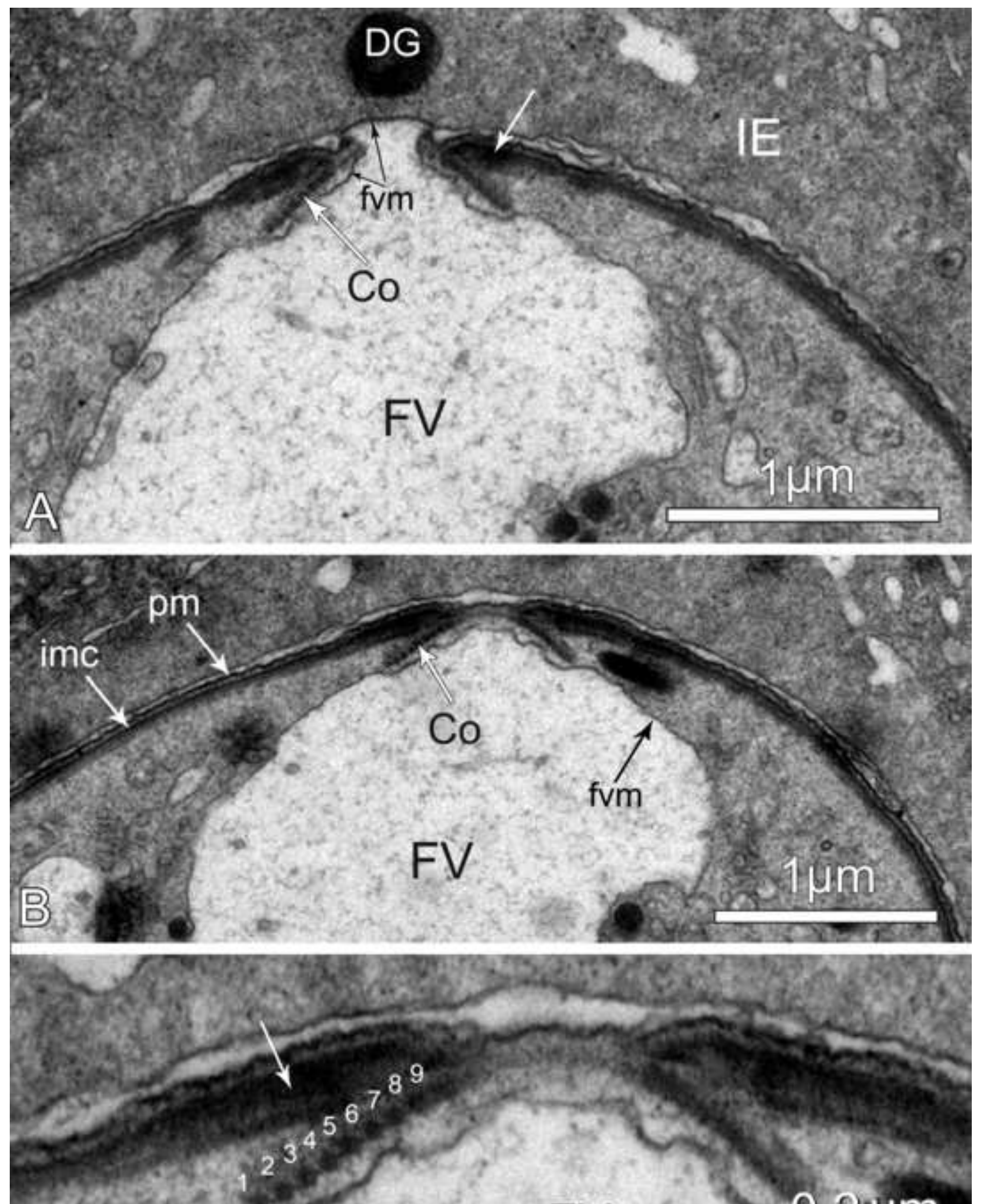

C

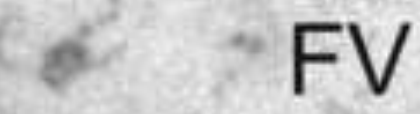

$0,24 \mathrm{~m}$ 


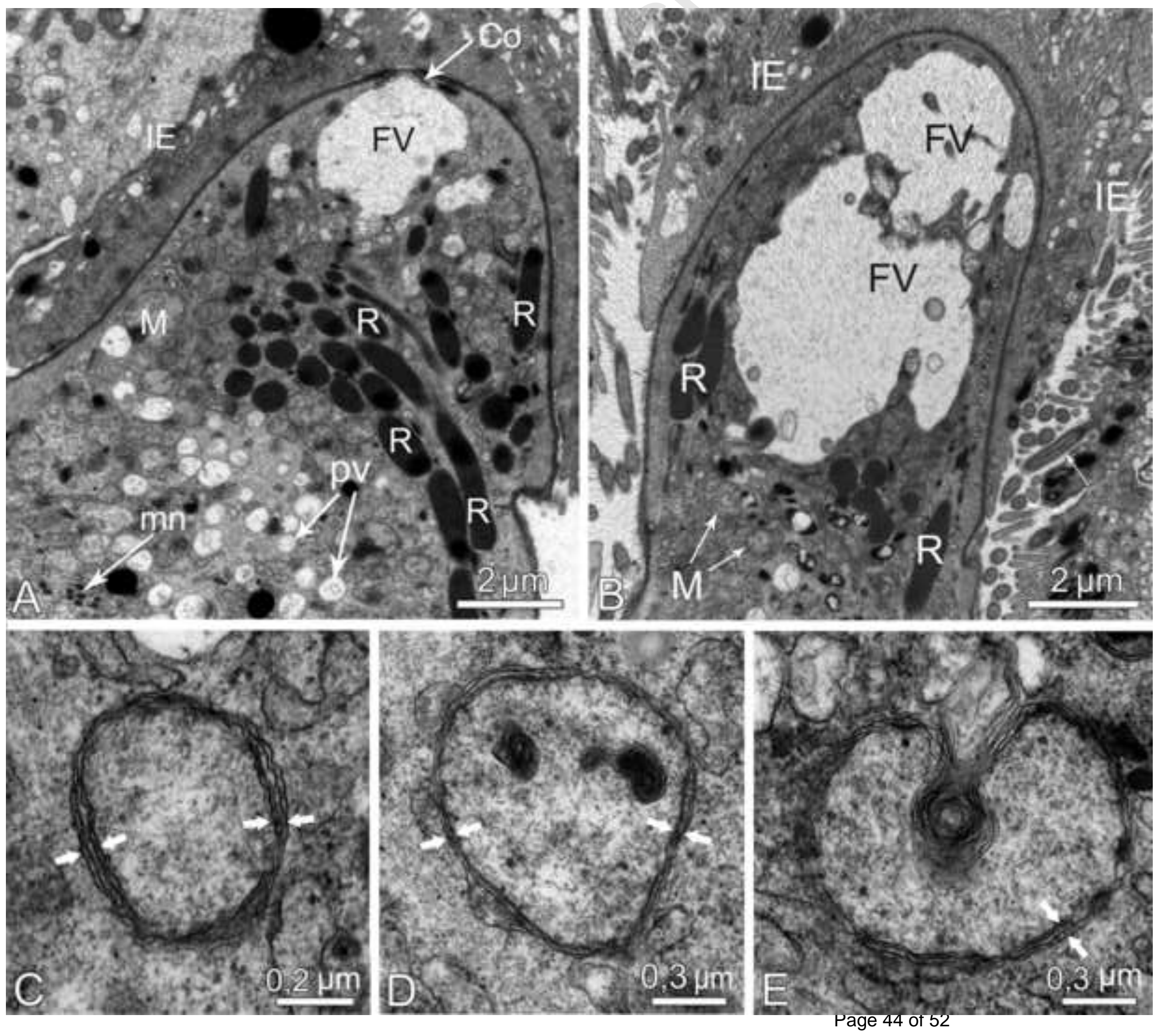



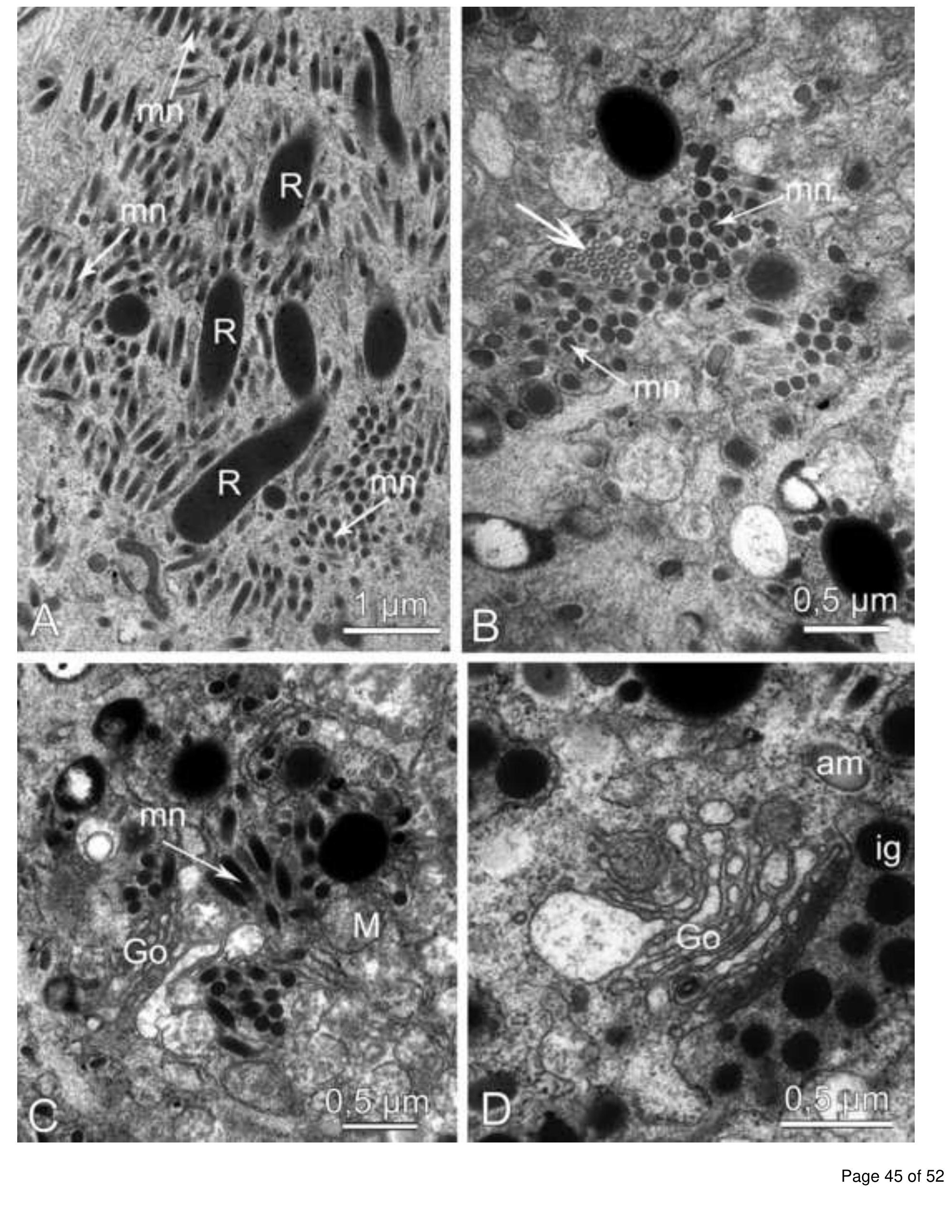

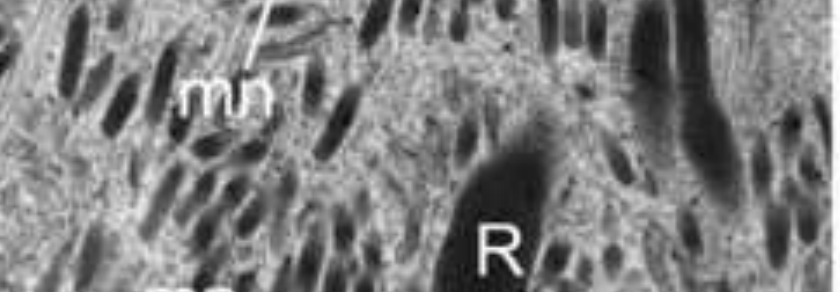

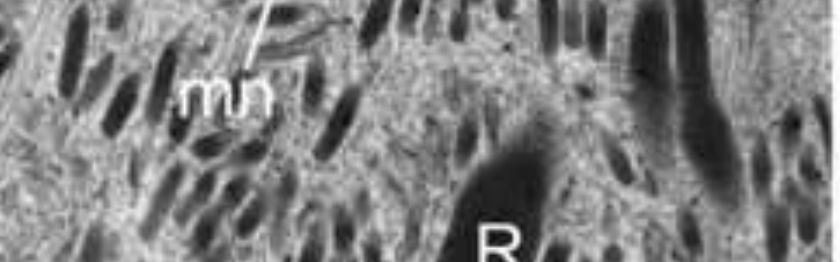

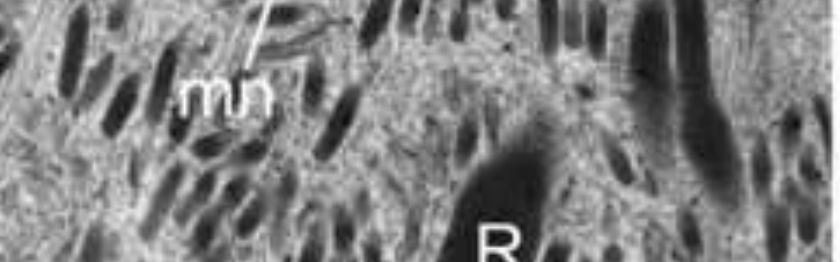

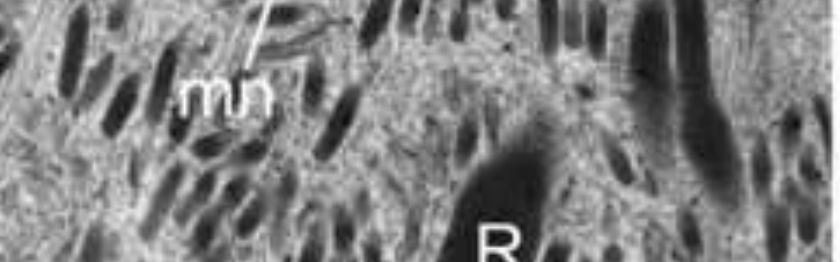

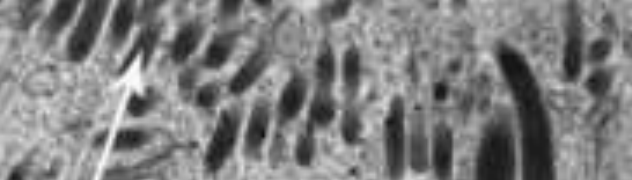
200 .

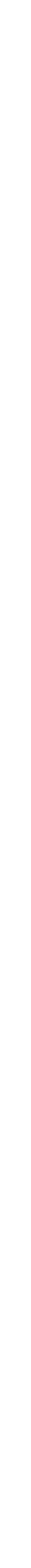



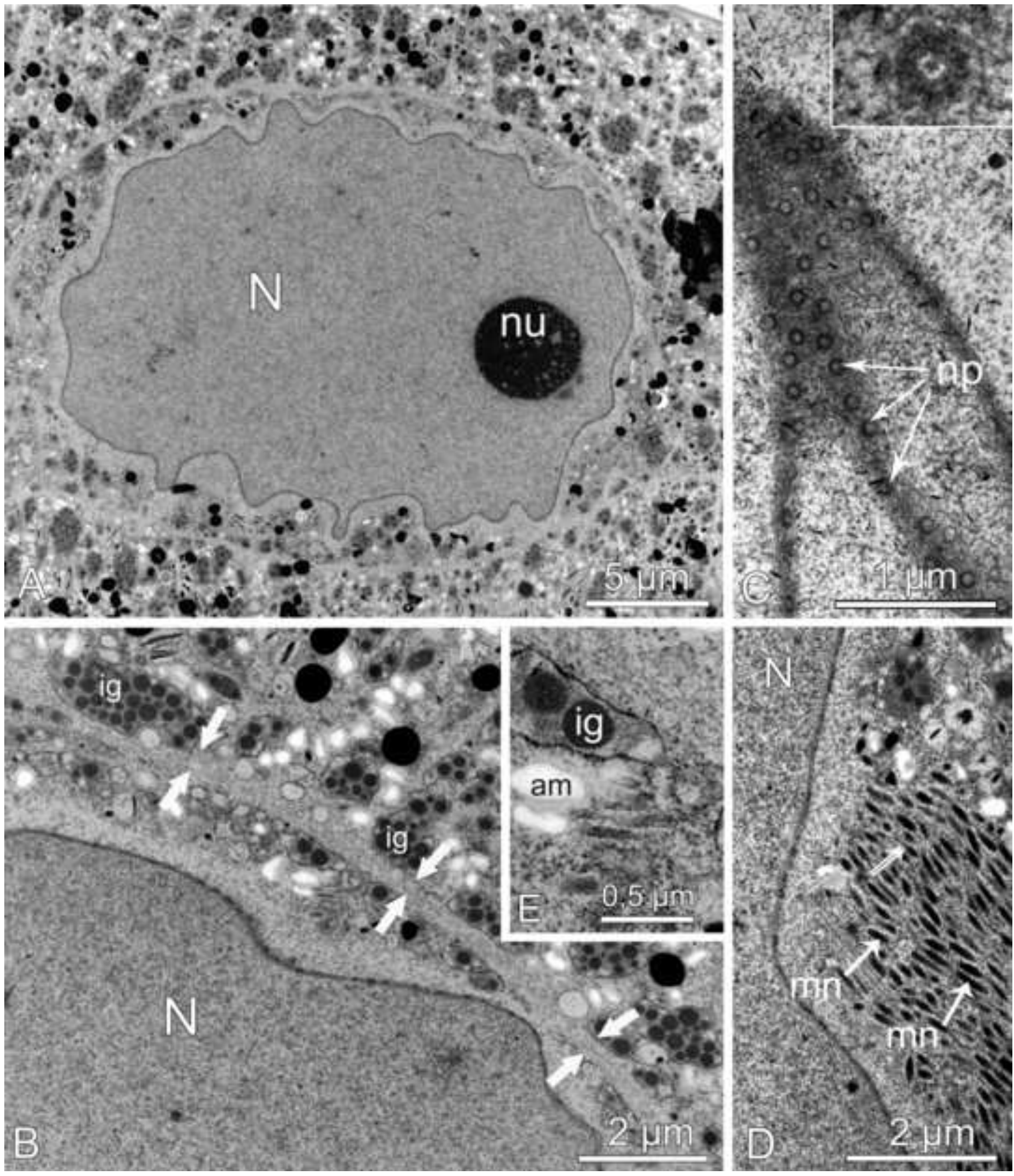

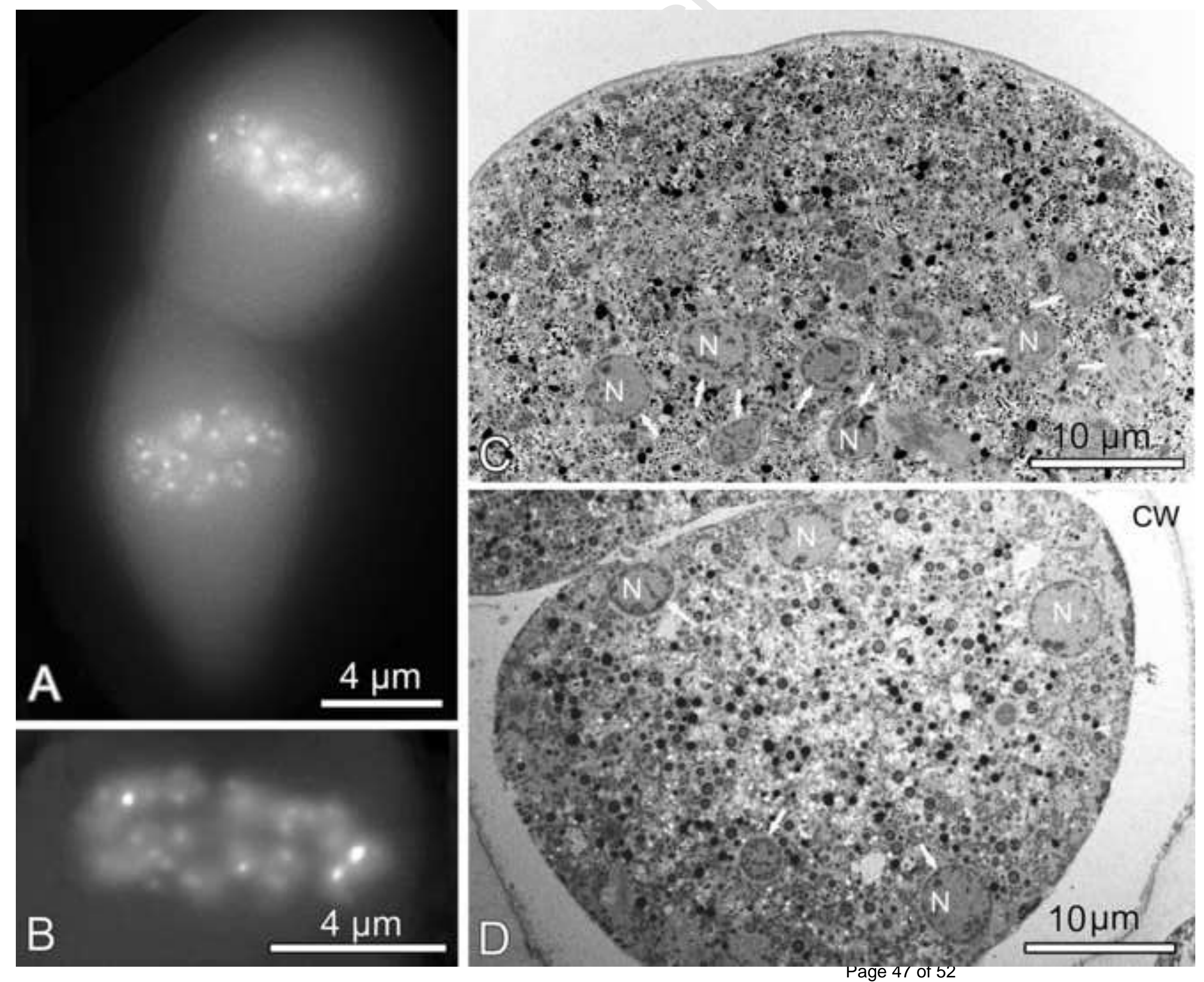

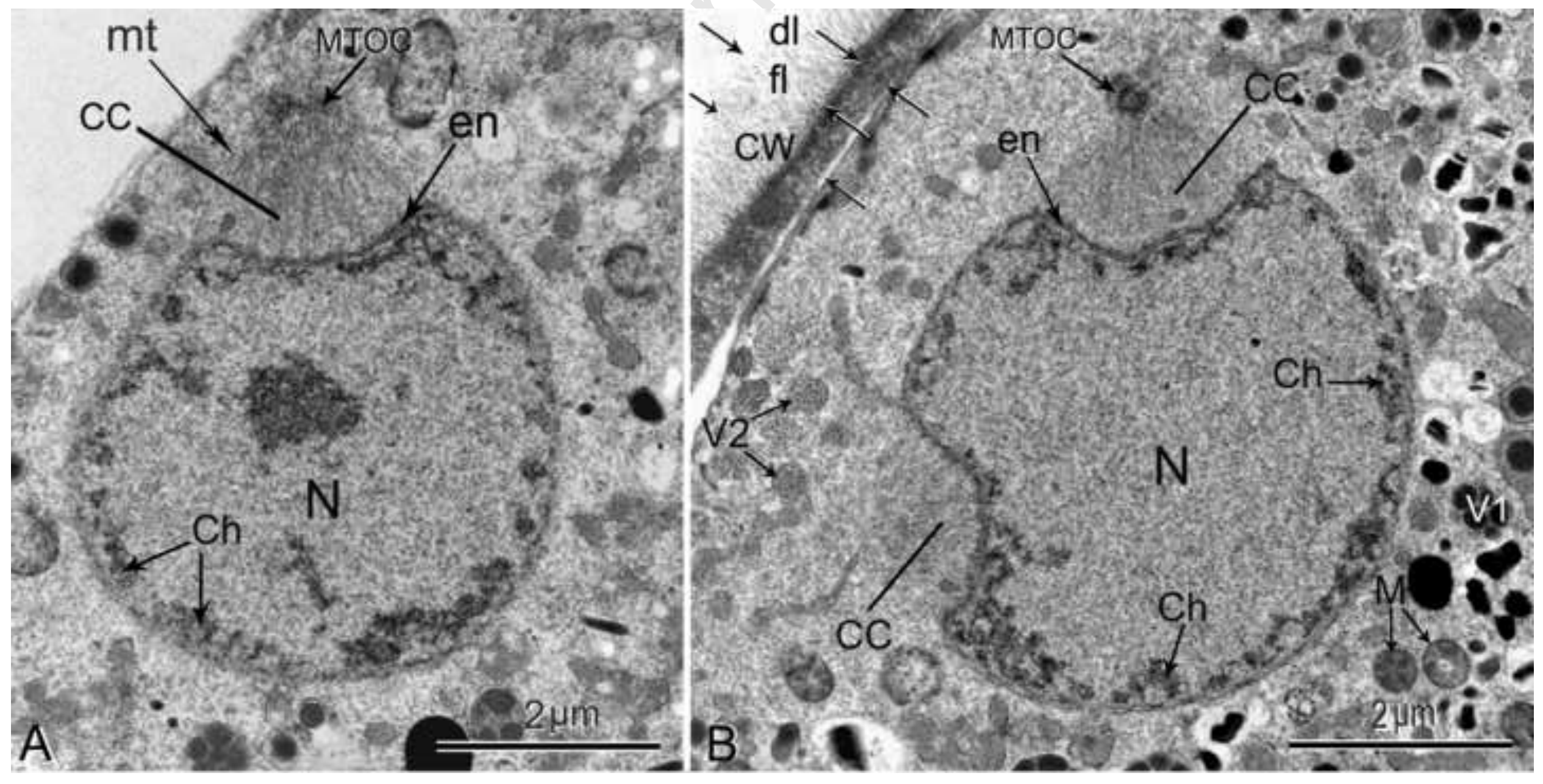

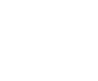

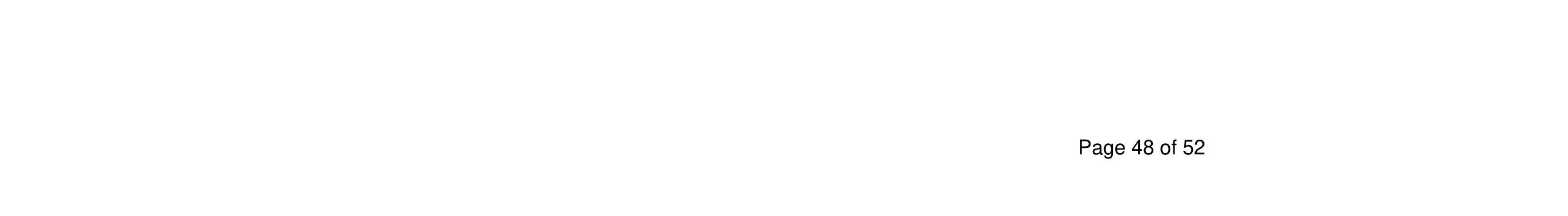

(

.

$$
\text { (n) }
$$

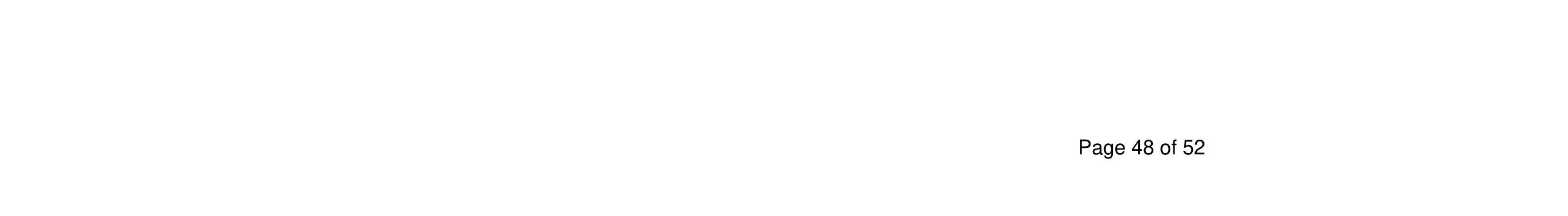

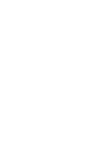

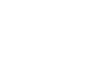

(n)
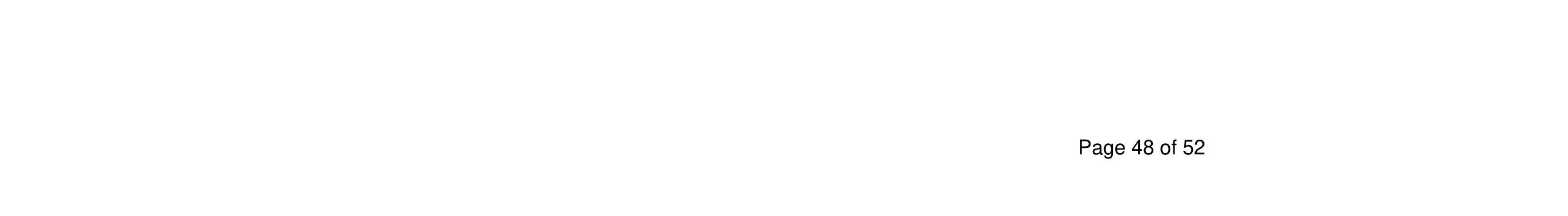

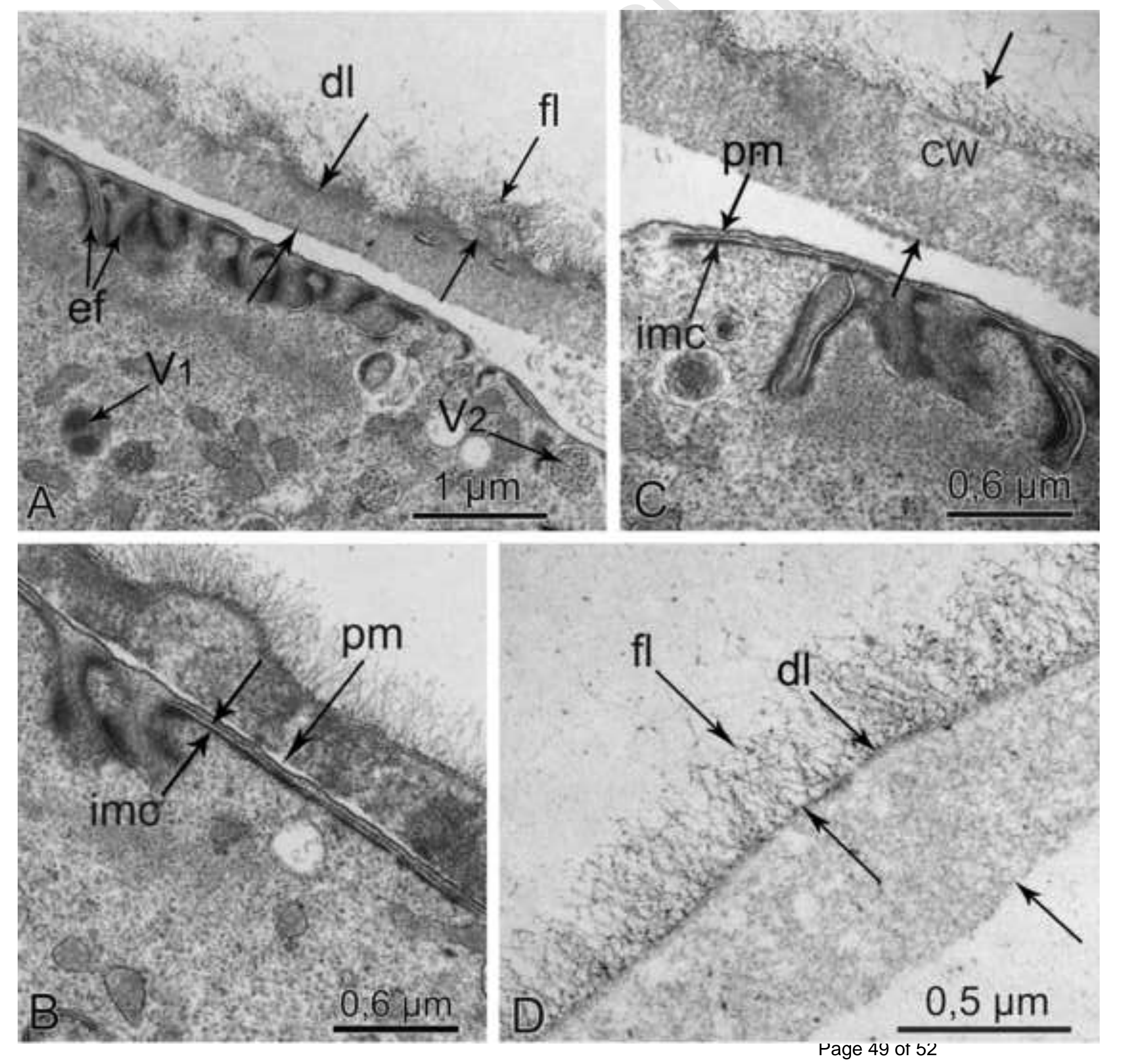

rage $4 y$ or 52

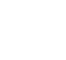

.
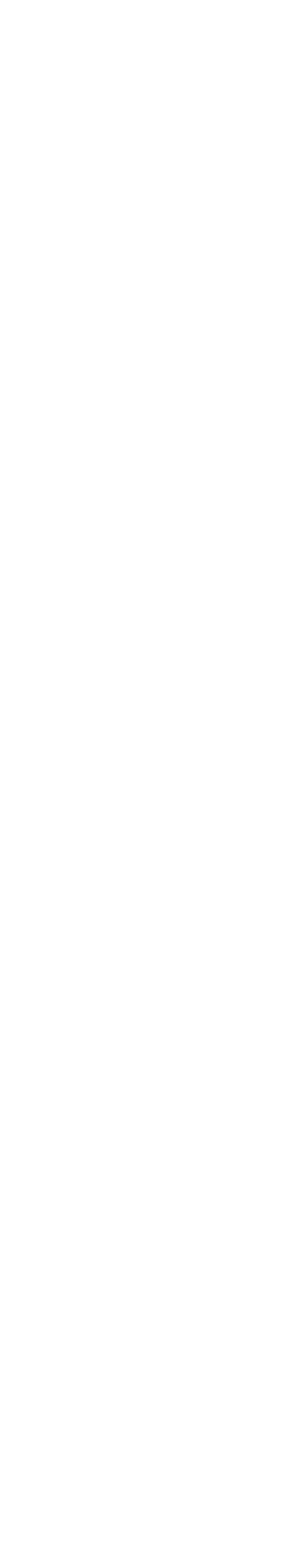

.

.
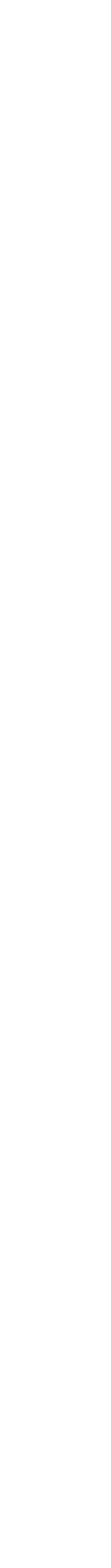


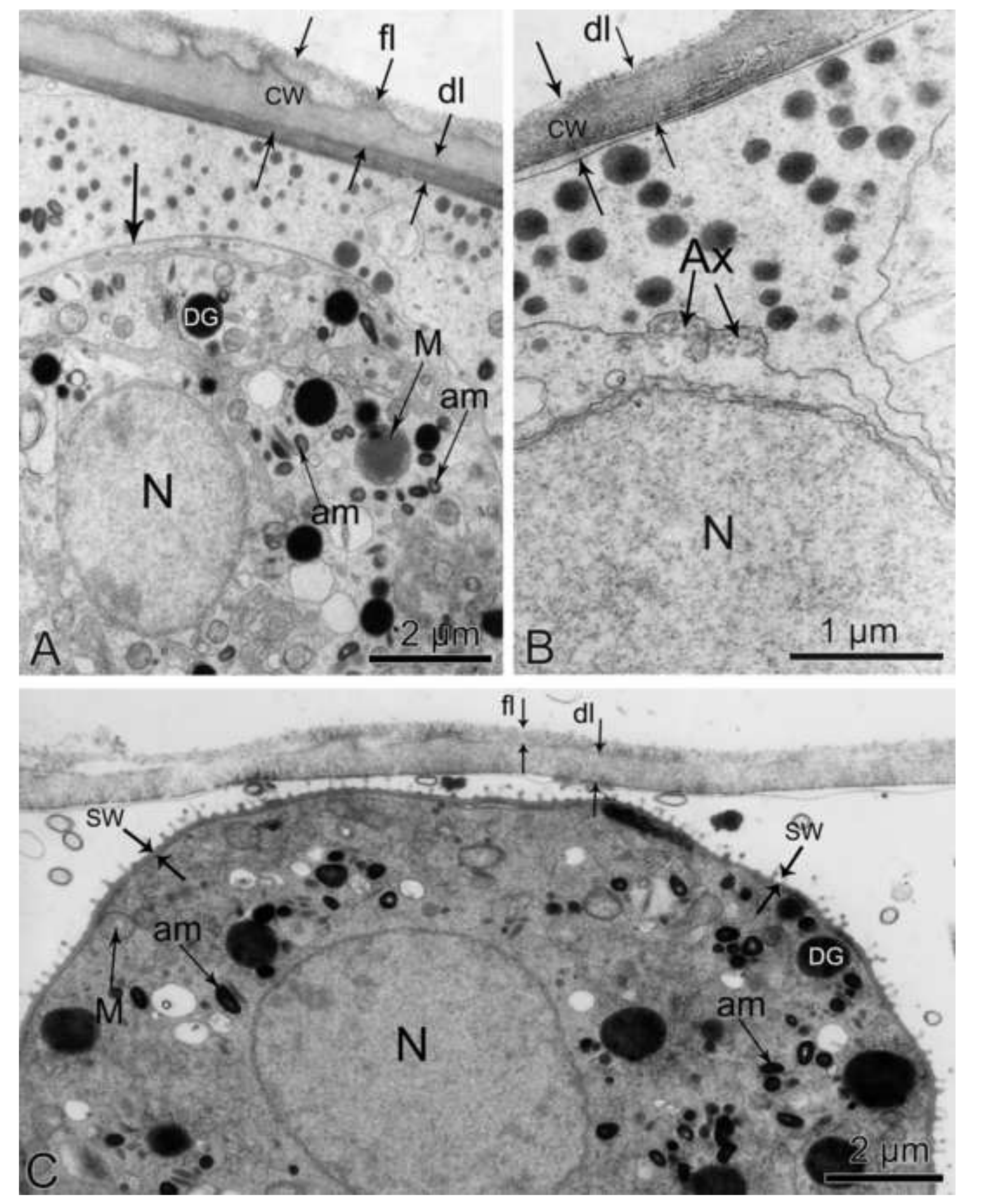

Fur

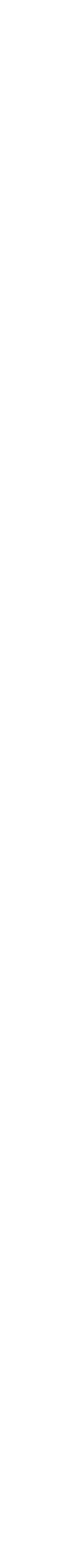

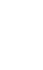

ACCEPTED MANUSCRIPT dl 
Figure $121000 \mathrm{dpj}$ Ascogregarina sp ex Ochlerotatus japonicus DQ462458
Ascogregarina culicis from Vietnam DQ462457

Ascogregarina culicis from Vietnam DQ

Ascogregarina taiwanensis from Japan DQ462454
Paraschneideria metamorphosa FJ459755

97/0.9 Ophryocystis elektroscirrha AF129883

94/0.9 - Mattesia geminata AY334568

Apicystis bombi FN546182

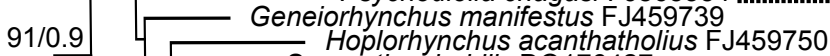

82/1 - Syncystis mirabilis DQ176427

Stylocephalus giganteus FJ459761

97/0.9 Stylocephalus giganteus FJ45970 Fismatophila watsonae FJ459738

77/0.6 Polyplicarum citrusae JX535336

179975

775/0.6 Uncultured eukaryote CCA38 AY

-- Lolyplicarum translucidae JX535348

- Uncultured eukaryote clone DSGM13 AB275013

- Uncultured alveolate clone AT416 AF530523

Diptera

Lepidoptera

Hymenoptera

Odonata, Hemiptera

Coleoptera, Lepismatids

Capitellid Polychaeta

Marine

gregarines

Blattaria, Orthoptera

Blabericola migratory FJ459754

$82 / 0.9$

Blabericola haasi FJ459753

-100/0.8 Gregarina blattarum F 345974

93/0.8 Amoebogregarina nigra FJ459737

$72 / 0.8$

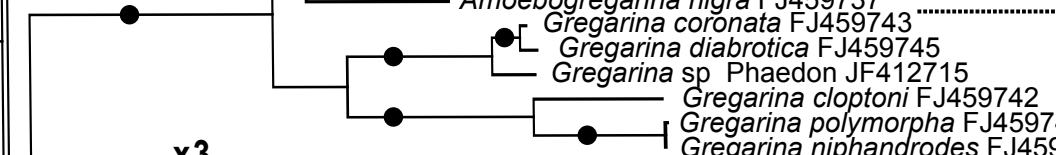

Gregarina polymorpha FJ459748

$\times 3$ Cephaloidophora cf communis HQ891111

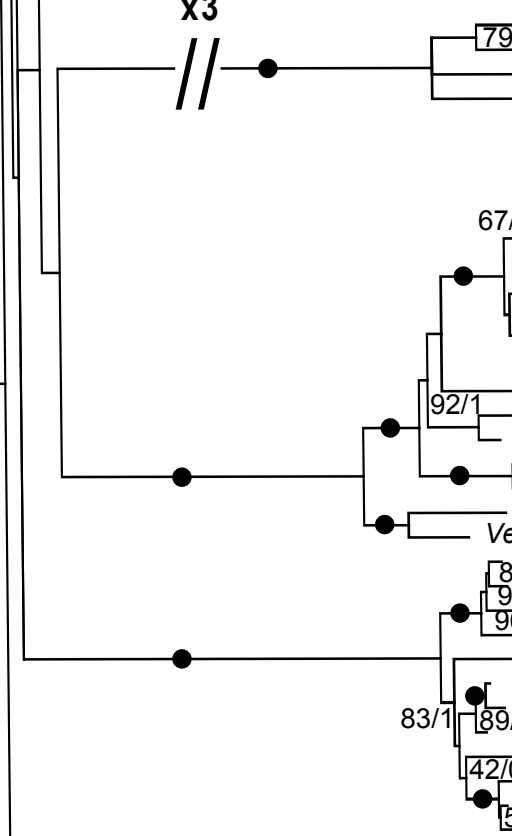

$54 / 0.7$ Selenidium neosabellariae KC110871

39/0.6_ Selenidium orientale FJ832161

Selenidium pisinnus FJ83232161

Selenidium melongena 2 KC890800

Selenidium terebellae 2 KC890804

Cryptosporidium serpentis AF15137

Cryptosporidium baileyi AJ276096

Cryptosporidium parvum AB08

Eimeria tenella AF026388

Toxoplasma gondii M97703

Besnoitia besnoiti AY833646

Babesia microti strain RI gi 399217317

90/1 Babesia bigemina JQ437264

[100/0.8 heileria parva L02366

Colpodella pontica AY078092

$48 / 1$ Colpodella pontlca AYronge AF 330214

43/0.8 Chromera velia strain CMS22 DQ174731

59/0.9 $\begin{array}{r}\text { Colpodella edax AY234843 } \\ \text { Alveolata sp CCMP3155 HM245049 }\end{array}$

-2 Parvilucifera infectans KF359485

44/1 Parvilucifera prorocentri $\mathrm{FJ} 424512$

44/1 Perkinsus atlanticus KF359485

Duboscquella sp AB295041 ${ }^{*}$

Ichthyodinium chabelardi FJ440623

Uncultured marine dinoflagellate clone

Syndinium turbo DQ146404

L Hematodinium perezi EF065717

97/1 Gonyaulax polyedra AF 377944

$72 / 1$ 97/1 Alexandrium catenella AY347308

Ganymedes sp SR2010 FJ976721

Lecudina tuzetae Roscoff 201 pugttiae HQ876006

Lecudina tuzetae Roscoff 2013 a LN901447

Lecudina tuzetae Roscoff 2013 L N N 901448

Lecudina tuzetae Roscoff 2012 LN901446

Lecudinazelae AF457128

Lankesteria abbotti DQ093796

98/1 Lankesteria ascidiae JX187607

88/0.9 Lankesteria cystodytae JF264840

Lithocystis sp DQ093795

Pterospora schizosoma DQ093793

Difficilina paranis DQ093794

Difficilina tubulani Fj832160

red eukaryote DSGM6 AB275006

Selenidium serpulae DQ683562

Selenidium sp2 KCW2013 KC110864

Selenidium cf echinatum KC110874

Selenidium pendula LN901444

Selenidium pendula LN901443
Selenidium boccardiellae JN857969

Selenidium cf mesnili JN857968

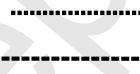

\author{
........
}

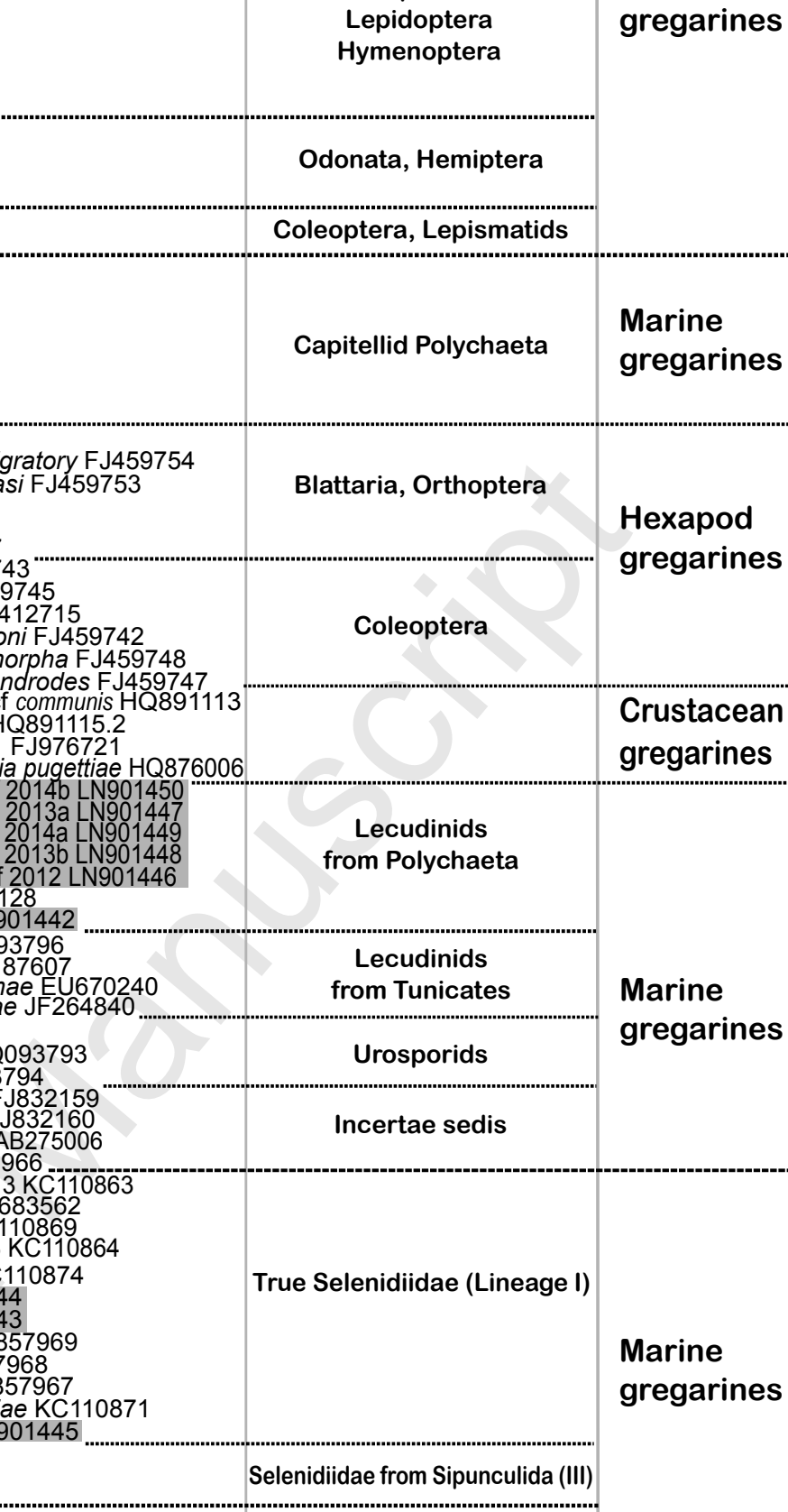

Selenidiidae from Sipunculida (III)

Selenidiidae from Terebellids (II)

47/0.7 Pfiesteria piscicida DQ991382

47/1 Akashiwo sanguinea AY831412

Prorocentrum micans AY803739

98/1 Saramecium tetraurelia AF149979

58/1 Sterkiella histriomuscorum FJ545743

Colponema edaphicum KF651068

Colponema sp Vietnam KF651083

5771 Chrysolepidomonas dendrolepidota

${ }_{57 / 1}$ Hyphochytrium catenoides X80344

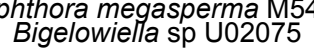


60 - Selenidium sp2 KCW2013 Isolate 2 KC110868

100 Selenidium sp2 KCW2013 Isolate 3 KC110864

L Selenidium sp2 KCW2013 Isolate 1 KC110865

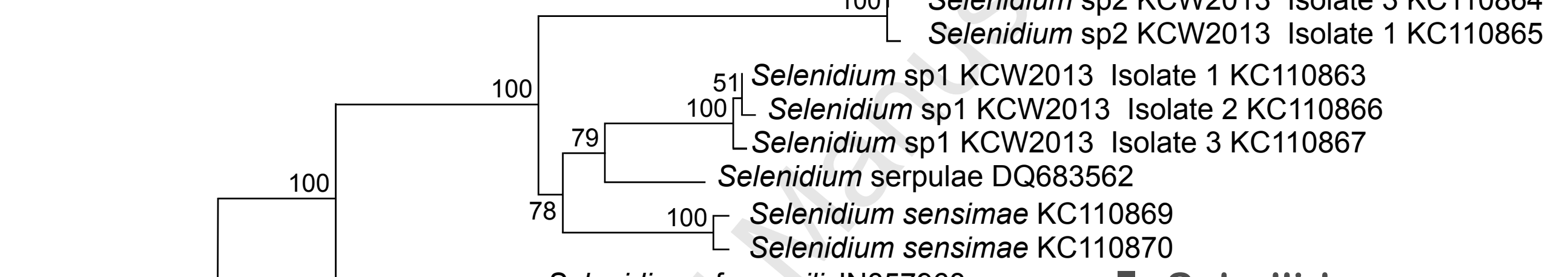

Selenidium cf mesnili JN857968

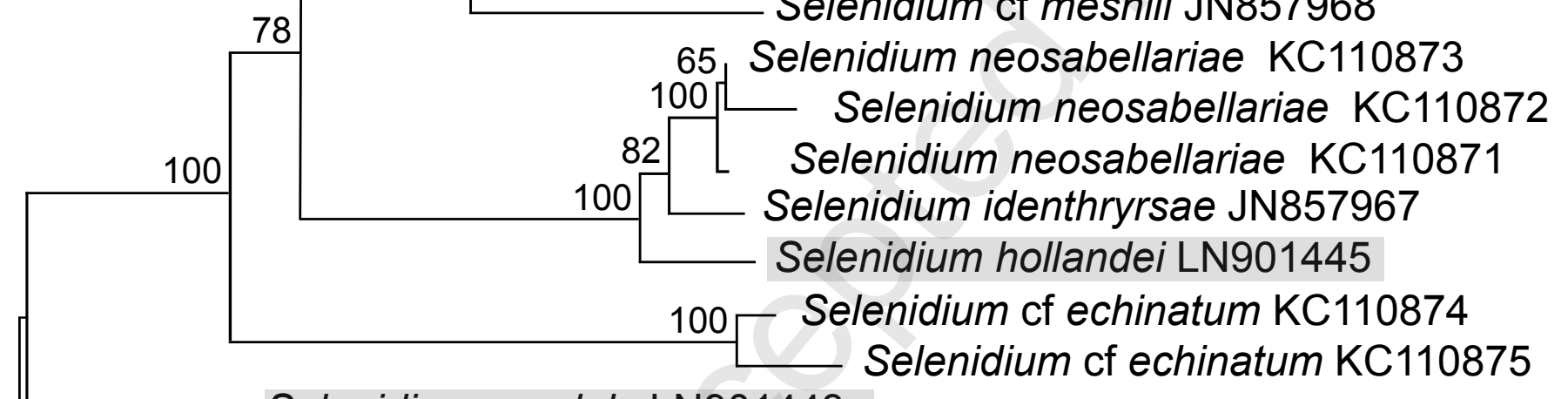

Sabellidae

Sabellaridae

Cirratulidae

$100[$ Selenidium pendula LN901444

Selenidium boccardiella JN857969
Spionidae 